NOTICE: this is the author's version of a work that was accepted for publication in the Journal of International Financial Markets, Institutions and Money. Changes resulting from the publishing process, such as peer review, editing, corrections, structural formatting, and other quality control mechanisms may not be reflected in this document. Changes may have been made to this work since it was submitted for publication. A definitive version was subsequently published in the Journal of International Financial Markets, Institutions and Money, Vol.32, (2014). DOI:

http://doi.org/10.1016/i.intfin.2014.07.002 


\title{
Political uncertainty and financial market uncertainty in an Australian context
}

\author{
Lee A. Smales, CFA \\ School of Economics \& Finance, Curtin University \\ Building 402, Level 5 \\ Kent Street \\ Bentley WA 6845 \\ Australia \\ Tel: +61 892661688 \\ Email: lee.smales@curtin.edu.au
}




\section{Political uncertainty and financial market uncertainty in an Australian context}

This paper seeks to investigate the influence of political uncertainty, surrounding the Australian federal election cycle, on financial market uncertainty. Measures of political uncertainty are constructed and their relationship with market uncertainty, as measured by implied volatility, explored. Empirical evidence suggests that increasing (decreasing) levels of uncertainty around the election induce higher (lower) levels of market uncertainty. An increasing likelihood of the incumbent party, whose economic policies are presumably well-known, winning the election, reduces market uncertainty. This relationship is stronger when political uncertainty is highest, when the business cycle contracting, and when the level of economic risk is high. Higher levels of political uncertainty tend to be associated with declining levels of outstanding debt, and lower issuance of long-term Government debt, driven by falling demand and higher yields.

Key-words: Political Uncertainty, Investor Sentiment, Financial Market Uncertainty, Implied Volatility, Exchange Traded Options, Stock Markets, Debt Issuance JEL Classification Codes: G1, G10, G15, G18, H3 


\section{Introduction}

The extant literature suggests that political factors may influence the risk premia inherent in financial assets. Hibbs (1986) suggests that differences in the economic policy of political parties have the potential to move the economy along different paths and results in different levels of return to both stock- and bond-holders. Johnson et al. (1999) examine the returns to several different asset classes in the period surrounding U.S. Presidential elections and report that while there is no difference in returns to large-cap stocks, returns to small-cap stocks are substantially higher during Democratic administrations, while Republican administrations result in superior bond market performance. This paper seeks to examine such relationships within the context of an electoral system with the non-U.S. characteristics of variable election timing and compulsory voting. Electoral polling data is utilised to construct measures of political uncertainty and the influence of this ambiguity on levels of implied market volatility and outstanding debt are considered within both an unconditional and economic-state-dependent framework.

Pastor and Veronesi (2012 and 2013) theorise a general equilibrium model which suggests that the risk-premium is affected by both economic shocks and non-economic shocks, such as political uncertainty. In their model there is an "old" policy with which investors become familiar with over time. Uncertainty is created since the government can endogenously choose a "new" policy from a range of options at any time. Once the new policy is chosen and announced, investors again learn about its impact. The model suggests that, independent of traditional risk factors, political uncertainty directly affects the risk premium. An important insight from Pastor and Veronesi (2013) is that the composition of the risk premium is state-dependent; in particular, political uncertainty constitutes a large fraction of the premium during economic contractions precisely because policy change is more likely during such times. Kelly, Pastor and Veronesi (2013) reinterpret this model in the context of an election; empirical evidence suggests that investors are willing to pay more for option protection in light of uncertainty around election results.

Empirical work has produced substantial evidence as to the influence of political outcomes on the stock market with market uncertainty rising as the day of voting approaches and uncertainty about the result increases. Li and Born (2006) study the period 1964-2000 and find that whilst the mean daily stock return rises in the 3-month period prior to U.S. elections when the outcome is uncertain, it is indistinguishable from the non-election period when the 
incumbent party is assured of re-election. Goodell and Vähämaa (2013) utilize data from the Iowa Electronic Market, a betting market for the U.S. Presidential election, and find support for the notion that information regarding the probability of a particular election winner reflects information about future macroeconomic policy. Julio and Yook (2012) provide evidence connecting political uncertainty to changes in fundamentals of the real economy as firms reduce expenditures during times of political uncertainty.

Several studies have attempted to form an international perspective on the political uncertainty-market uncertainty relationship: Gemmill (1992) discovers a close relationship between U.K. polling and the FTSE Stock Index, Pantzalis et al. (2000) report that the connection between political uncertainty and the stock market differs in depending on the level of political, economic and press freedom, while Bialkowski et al. (2008) investigate a sample of 27 OECD countries and find that stock market return variance doubles during the week around the election. Importantly, the margin of victory and changes in political orientation of government are key factors in explaining the magnitude of the election surprise.

There has also been some consideration as to how elections may impact the fiscal policy of Government. Drazen and Eslava (2010) examine investment spending by Government in the period around Colombian elections and show that investment spending tends to increase prior to the election, and has a positive impact on the incumbent's re-election prospects. Veiga and Veiga (2007) demonstrate that similar behaviour exists in Portugal, and is more prevalent when the win-margin is small. Casette and Farvaque (2014) suggest that while the average level of debt has a negative impact on the probability of re-election, pre-election debt accumulation by incumbents increases their probability of re-election. Gao and Qi (2013) investigate the influence of political uncertainty around U.S. gubernatorial elections on the borrowing costs of public debt, measured by yields of municipal bonds, and report that yields increase sharply before elections and then reverse afterwards.

In the sense that elections impact the macro-economy of a nation through the mechanism of fiscal and economic policy followed by the Government, this study is related to the broader field of research into the impact of news announcements on market uncertainty. The general result (Ederington and Lee, 1996; Nikkinen and Sahlström, 2004; Smales, 2013) being that an upcoming macroeconomic announcement creates uncertainty which quickly dissipates once the data is released. Of particular relevance, Nikkinen and Sahlström (2004), Vähämaa, Watzka and 
Äijö (2005), Chen and Clements (2007) and Vähämaa and Äijö (2011) examine the behaviour of implied volatility around macroeconomic announcements and document that, having risen prior, implied volatility falls following the broadcast as uncertainty is resolved. There has been little empirical work on implied volatility indices in the Australian context to-date. However, Frijns et al. (2010) construct an implied volatility index for the Australian equity market and observe a significant and asymmetric relationship between the volatility index and stock returns; echoing prior findings in U.S. markets.

Essentially, this paper asks a single key question: does political uncertainty impact financial market uncertainty? Relating this question to prior research, three hypotheses are formulated.

$\mathrm{H}_{1}$ : An increase (decrease) in political uncertainty will lead to an increase (decrease) in market uncertainty as measured by implied volatility - i.e. there is a positive relationship.

$\mathrm{H}_{2}$ : Familiarity with the economic policies of the incumbent party, will result in market uncertainty falling (rising) as the likelihood of the incumbent party winning the election increases (decreases) - i.e. there is a negative relationship.

$\mathrm{H}_{3}$ : Congruent to the theoretical model of Pastor and Veronesi (2013), political uncertainty will play a more important role in determining market uncertainty during periods when the economy is weaker; this is when policy change, and also change in government, is most likely.

Whilst the empirical framework utilised in the first section of this paper is similar to that employed by Goodell and Vähämaa (2013) this paper still succeeds in making several contributions to the existing literature. Firstly, in contrast to Goodell and Vähämaa (2013) who assume the outcome of the election is known a priori, I use polling data to construct unique measures of ex-ante political uncertainty. Secondly, prior work has focused heavily on equity markets and largely ignored bond markets yet it is likely that a change in government would also have an impact on bond yields, particularly through fiscal policy, and therefore this study attempts to rectify that prior omission. Third, this paper provides empirical evidence as to the circumstances under which political uncertainty has a particularly important influence on financial market uncertainty. Fourth, this paper contributes to the extant literature by examining how political uncertainty affects the process of debt issuance. Finally, by extending the existing 
work to an Australian dataset the results are placed in the context of an electoral system that has very different characteristics in so far as there exists variable timing ${ }^{1}$ of federal elections, a twoparty preferred voting system, and where voting is also compulsory.

The empirical findings establish a clear relationship between Australian financial market uncertainty, as measured by implied volatility, and political uncertainty around federal election polling. In particular, the implied volatility of both equity and bond options increases in line with election uncertainty around the outcome of the poll result. The likelihood of the incumbent remaining in power reduces market uncertainty; consistent with the market preferring incumbents where economic policy is known. The results are significant even after controlling for macroeconomic variables and the possibility that economic conditions may affect voting intentions. Further investigation reveals that market uncertainty appears to be most sensitive to political uncertainty when such uncertainty is highest (i.e. when polling results are closest), when the business cycle is in contraction, and when the level of economic risk is high. In addition, higher levels of political uncertainty tend to be associated with declining levels of outstanding debt, and lower issuance of long-term Government debt, driven by falling demand and higher yields.

The remainder of this paper proceeds as follows. The second section provides background information on the nature of Australian federal elections and also describes the election, financial and macroeconomic data used in the empirical analysis. The third section presents methodology and reports the empirical findings on the role of political uncertainty in the uncertainty of equity and bond markets. Finally, section four provides concluding remarks and suggestions for future research.

\section{Data}

\subsection{Election Uncertainty in Australian Federal Polls}

Whilst the Australian Parliament has an upper house (the Senate) it is the election for the lower house (the House of Representatives) that is of most interest to this study as the outcome forms the basis for Government; a full-preference instant runoff voting system is used in which voters number the candidates on the ballot paper in the order of their preference ${ }^{2}$. House

\footnotetext{
${ }^{1}$ The election can be held a maximum of 3-years after the Parliament sits following the prior election.

${ }^{2}$ See www.aec.gov.au for more detailed information.
} 
elections take place at least every 3 years, with the 2010 election resulting in the first hung parliament since 1940 .

Whilst the Australian political system consists of many political parties, only two have a realistic chance of winning sufficient representation in the House to form a government. As such, there is a de facto two-party system with the Australian Labor Party (ALP) at the socialist (left) end of the political spectrum and the Liberal-National Party (L-NP) Coalition ${ }^{3}$ espousing more conservative (right) views. Traditionally, the ALP has had a predilection for fiscally expansionary policy that favours workers and unions, while the L-NP has in general favoured smaller government and policy that favours business. At the most basic level the differences between Australian political parties are analogous in many ways to that between the Democratic (Labour) Party and the Republican (Conservative) Party in the U.S. (U.K.).

In the eight federal elections held in Australia since 1993, the stock market has risen by an average of $2.2 \%$ in the month prior to a L-NP election win, and fallen by $0.9 \%$ in the month prior to an ALP win. In the month subsequent to the election result, the stock market has rallied by $2.2 \%$ on average regardless of the winner. Once election uncertainty is resolved on polling day, volatility measures fall by $24.9 \%$ (13.7\%) following L-NP (ALP) success. This suggests that the stock market rises (falls) in anticipation of business friendly (unfriendly) policies by the L-NP (ALP) and then continues to rise as uncertainty about the election and subsequent policies is resolved. The reaction to electoral results is somewhat different in the bond markets. Yields on 5year government bonds rise by 3.7\% (9.3\%) on average following L-NP (ALP) poll wins, and the change in yields in more pronounced when comparing to changes in U.S. yields over the same time period; Australian yields rise by $10 \%$ (1.2\%) more than comparative U.S. yields in the month prior to an ALP (L-NP) win and while yields continue to rise relative to those in the U.S. in the aftermath of an ALP win, they actually fall (by $4.0 \%$ on a relative basis) following a L-NP win. Likely, this result owes much to the market reflecting differences in economic policy inherent within the two parties, and in particular the expansionary fiscal policy generally pursued by the ALP.

The two-party preferred vote (2PP) is the result of an election or opinion poll after preferences have been distributed to the two major parties. Owing to the nature of the Australian

\footnotetext{
${ }^{3}$ Officially, the Coalition consists of the Liberal Party of Australia, the National Party of Australia, the Liberal National Party and the Country Liberal Party.
} 
electoral system, the two-party preferred vote data collected by polling companies is of particular interest when seeking to determine the likely winner of forthcoming elections. This study utilizes federal voting intention data expressed as a two-party preferred vote provided by Roy Morgan Research; a leading independent polling company ${ }^{4}$. Figure 1 - Panel A depicts how the ALP and L-NP have performed in the opinion polls for the five Federal elections in the 2000 - 2013 timeframe on the basis of $2 \mathrm{PP}$ polling.

In this study, the release of the poll is defined as the date on which it could begin to influence financial market returns. For example, if a poll is released on a Sunday then the next trading day is taken to be the poll date. For each election year, I examine polls for the calendar year prior to polling day; since polls are generally released on a fortnightly basis this will give a base sample of 26 fortnightly releases of polling data, to which is added additional weekly polls that take place in the period immediately prior to the election data ${ }^{5}$.

Whilst Goodell and Vähämaa (2013) introduce two measures of political uncertainty based on the $e^{x}$-post probability of the eventual winner succeeding, this paper focuses on $e x$-ante measures of the election uncertainty around the incumbent government; this seems to be a more realistic measure of election uncertainty, reflecting information that is available to option traders in the bond and equity markets at the time polling data is actually released. $I U_{n, t}$, a measure of Australian federal election uncertainty is constructed, where $n$ refers to the election year and $t$ refers to the time until the election date. The 2PP opinion poll result for the party out of power, $O_{n, t}$, is subtracted from the $2 \mathrm{PP}$ result for the party of the incumbent Prime Minister, $I_{n, t .}$. The difference is then divided by the poll's sampling $\operatorname{error}^{6}\left(\sigma_{n, t}\right)$ :

$$
I U_{n, t}=\left(I_{n, t}-O_{n, t}\right) / \sigma_{n, t}
$$

\footnotetext{
${ }^{4}$ Roy Morgan Research was founded in 1941 and as well as being the longest established public opinion polling company in Australia, is independent from ownership by any media companies, and it's opinion polls were most accurate in forecasting the outcome of the Australian federal elections during the timeframe considered in this study.

${ }^{5}$ To ensure consistency of the polling data I exclude telephone-based polls from the sample owing to their well-documented selection bias.

${ }^{6}$ Sampling error information is based on the number of people taking part in the sample and is provided by the polling company at the same time the poll results are released; this "margin of error" is normally within the range of $2-4 \%$
} 
$E U_{n, t}$ is introduced as a second measure of election uncertainty. $E U_{n, t}$ captures the difference between the probability of re-election of the incumbent party, and the probability of the other party winning the election. $E U_{n, t}$ is defined:

$$
E U_{n, t}=1-\left|P I_{n, t}-\left(1-P I_{n, t}\right)\right|
$$

Where $P I_{n, t}$ denotes the probability of success of the incumbent party. When both parties have an equal probability to become elected (i.e. $\left.P I_{n, t}=0.5\right)$ then $E U_{n, t}$ equals one. When either of the parties is certain to win the election (i.e. $P I_{n, t}=0$ or 1 ) then $E U_{n, t}$ equals zero. The test variables utilised within the empirical analysis are $\% \Delta I U_{n, t}$ and $\% \Delta E U_{n, t}$ - the percentage change in the respective measures of electoral uncertainty.

\subsection{Financial Instruments and Macroeconomic Data}

The financial instruments utilized within the empirical analysis are exchange-traded futures and options contracts based on the S\&P/ASX 200 (the leading benchmark for Australia's equity markets) and the 3-year Treasury Bond (the most actively traded Australian bond futures contract). Daily closing data is collected from Thomson Reuters Tick History (TRTH), provided by SIRCA ${ }^{7}$, and the Australian Securities Exchange ${ }^{8}$. To ensure that the study concentrates on the most liquid contracts only the nearest futures contracts are considered. In-line with market convention, the contract under consideration is rolled on the last day of the month preceding the delivery month.

A measure of implied volatility is constructed using the daily closing levels of ATM call and put options; the closing implied volatility level of the two nearest to expiry option contracts are interpolated in order to ensure a constant option maturity of 30 days. This produces a measure, $\sigma_{n, t}^{S P X}$, that represents the expected volatility of the S\&P/ASX 200 (SPX) over the next 30-days, and is similar in fashion to the widely used CBOE VIX index. Similarly, $\sigma_{n, t}^{3 Y B}$ represents the expected volatility of 3-yr Treasury bond futures over the same period. Figure $1-$ Panel B ${ }^{9}$ depicts how each measure moves over time in the period around the four elections considered in this article. Note the spike in equity market volatility around the events of September 2001, and the apparent positive relationship between volatility and the 2PP for the ALP.

\footnotetext{
${ }^{7}$ Securities Industry Research Centre of Asia-Pacific

${ }^{8}$ www.asx.com.au

${ }^{9}$ Note that since the implied volatility measure is general much lower for bonds than for equity markets, the measures are re-scaled in order to provide clarity of the evolution of each measure over time.
} 
Since option implied volatility incorporates all available information that is relevant for forming expectations about future volatility, implied volatility is widely considered as the best estimate of market uncertainty. In this study, the variables of interest are $\% \Delta \sigma_{n, t}^{S P X}$ and $\% \Delta \sigma_{n, t}^{3 Y B}$, the percentage change in the implied volatility level of the S\&P/ASX 200 Index options and 3year Treasury Bond options respectively.

Changes in economic optimism and changes in expectations regarding macroeconomic risk will likely impact voting preferences, financial asset prices and market sentiment; therefore, a number of macroeconomic variables are included as control variables. \% IINFL is the percentage change in inflation as reported by the Australian Bureau of Statistics (ABS). Periods of increasing inflation are typically associated with increases in economic activity and more restrictive changes in monetary policy. \% $\triangle U N E M P$ is the monthly percentage change in unemployment reported by the ABS. $\% \triangle A S X$ is the percentage change in the S\&P/ASX200 Index. \% CONSCONF is the monthly percentage change in consumer confidence as reported by Westpac / Melbourne Institute, and it would be expected that rising consumer confidence would follow from rising stock markets and falling unemployment. $\% \triangle R B A C R$ is the percentage change in the official cash target rate of the Reserve Bank of Australia (RBA); this measure is included since it is the main instrument of monetary policy and influences many facets of economic activity. \% $\triangle A U D T W I$ is the percentage change in the trade-weighted-index of the Australian dollar. The change in slope of the yield curve ${ }^{10}, \Delta 3 s 10 \mathrm{~s}$, is included since this provides information on market expectations of future economic activity and future changes in interest rates. Finally, an economic risk rating (ERR) index is introduced as an alternative means of controlling for economic influences. The ERR index ${ }^{11}$ assigns risk points to a pre-set group of factors, termed economic risk components, that includes GDP, annual inflation, the budget balance and current account balance. A lower (higher) risk point total indicates a higher (lower) level of economic risk within the country.

$<$ Insert Table I $>$

\footnotetext{
${ }^{10}$ Yield curve slope is measured as the difference between the yields on 3- and 10-yr Treasury Bonds.

${ }^{11}$ Obtained from the PRS group (https:/www.prsgroup.com/). This index is only available on a monthly basis so a log change in the monthly ERR is calculated and then allocated to each day in the particular month to which it relates. This provides a series of daily log changes in ERR for each period in the sample.
} 
Table I provides summary statistics for all of the variables used within the empirical analysis. The table shows that the mean and standard deviation for both implied volatility measures was highest in the period prior to the 2007 federal election; notably this was the incumbent L-NP lost at the polls. The mean values of the measures of political uncertainty are relatively minor but exhibit a relatively large standard deviation; $\% \Delta I U_{n, t}$ was highest prior to the 2004 election and $\% \Delta E U_{n, t}$ highest prior to the 2010 election. Clearly, $\% \Delta I N F L$ has been the most volatile macroeconomic variable over the period considered, although it is interesting to note that this measure was generally declining whilst L-NP was the incumbent party and was increasing prior to the 2010 election when the ALP was incumbent.

Table II provides the Pearson correlation coefficients between the variables used in the regression analysis of this paper. Note the negative correlation between $\% \Delta I U_{n, t}$ and implied volatility measures, and the positive correlation between $\% \Delta E U_{n, t}$ and implied volatility measures; implied volatility declines as the incumbent becomes more likely to win since market participants have a greater understanding of the economic policies of the incumbent, while implied volatility increases as election uncertainty increases. Unsurprisingly, there is a positive relationship between the implied volatility measures for equity and bond markets. In-line with the findings of Whaley (2009) there is a significantly negative relationship between $\% \triangle A S X$ and implied volatility, that is implied volatility rises as the stock market declines and vice-versa. The correlation between the macroeconomic variables makes intuitive sense as rising (falling) interest rates (RBACR) would likely be commensurate with rising (falling) inflation, falling (rising) unemployment, rising (falling) consumer confidence, and a rising (falling) Australian Dollar.

\section{$<$ Insert Table II $>$}

\section{Empirical Results}

\subsection{Implied Volatility and Political Uncertainty}

The first stage in the empirical analysis of the role that political uncertainty plays in influencing implied volatility, and hence market uncertainty, is to perform a regression of the form:

$\% \Delta \sigma_{n, t}^{i}=\alpha+\beta_{1} \% \Delta I U_{n, t}+\beta_{2} \% \Delta E U_{n, t}+\beta_{3} \% \Delta \sigma_{n, t-1}^{i}+\sum_{n=1}^{k-1} \lambda_{n}$ election fe $\mathrm{e}_{n, t}+\varepsilon_{n, t}$

Where $\% \Delta \sigma_{n, t}^{i}$ is the percentage change in implied volatility of instrument $\mathrm{i}$ (that is S\&P/ASX 200 or the $3-y r$ government bond), $\% \Delta I U_{n, t}$ is the percentage change in the likelihood 
of the incumbent party winning the election, $\% \Delta E U_{n, t}$ is the percentage change in election uncertainty, election fe $e_{n, t}$ are control variables for election fixed effects, and $\varepsilon_{n, t}$ is the error term. A one-period lagged percentage change in implied volatility is included since the volatility of the financial instruments considered is mean-reverting.

\section{$<$ Insert Table III $>$}

Table III reports the results for the regression presented in Eq. (3), a disaggregation of the model into each of the election periods considered is also presented in order to allow for analysis of how the relationship has evolved over time. In consideration of the aggregate panel models, for the fixed effect specification makes it clear that the level of implied volatility decreases as the probability of the incumbent winning increases although this is only significant for equity options, providing evidence that uncertainty is lower when the prospective economic policy of election winners is known to the market; if the likelihood of the incumbent winning increases by $1 \%$ then implied volatility decreases by approximately $0.5 \%$. Election uncertainty has a significant positive effect on the implied volatility of both equity and bond option markets although the magnitude of the effect is greatest for SPX options; a $1 \%$ increase in election uncertainty results in a $0.8 \%$ increase in SPX implied volatility and a $0.16 \%$ increase in 3-yr bond option implied volatility. Upon consideration of the disaggregated model, the influence of election uncertainty on implied volatility is apparently declining over time for both equity and bond options.

Given the historical performance of Australian financial markets in the proximity of federal elections conditional on different parties winning, it is possible that changes in implied volatility may differ dependent on the polling performance of a preferred party. A second equation is introduced:

$$
\begin{aligned}
\% \Delta \sigma_{n, t}^{i}= & \alpha+\beta_{1} \% \Delta I U_{n, t}+\beta_{2} \% \Delta E U_{n, t}+\beta_{3} \% \Delta I U \cdot L N P_{-} \text {Incumbent }_{n, t}+\beta_{4} \% \Delta \sigma_{n, t-1}^{i} \\
& +\sum_{n=1}^{k-1} \lambda_{n} \text { election fe }_{n, t}+\varepsilon_{n, t}
\end{aligned}
$$

Where $\% \Delta I U \cdot L N P_{n, t}$ is an interaction term between percentage changes in the level of incumbent uncertainty and a dummy variable indicating that the L-NP is the incumbent party; effectively controlling for uncertainty when L-NP is incumbent. The other variables are defined as for Eq. (3). The results for Eq. (4) are presented in Table IV. Election uncertainty has a significant positive impact on both measures of implied volatility; that is implied volatility 
increases when election uncertainty rises. Additionally, the lagged implied volatility term is significantly negative in a confirmation of mean reversion. Interestingly, $\% \Delta I U$ is no longer significant, or negative, as before however the interaction term with change in L-NP incumbency is both significant and negative. This result suggests that market uncertainty is actually responding to changes in the possibility that the L-NP Coalition will be re-elected, and effectively implied volatility measures fall if the likelihood of the L-NP remaining in power increases.

\section{$<$ Insert Table IV >}

In order to gain an understanding as to the circumstances under which election uncertainty is most important, Eq. (4) is augmented by a series of dummy state-variables that indicate whether the electoral polling is close ${ }^{12}$ (i.e. there is most uncertainty about the election outcome), whether economic conditions indicate high levels of economic risk ${ }^{13}$, and whether the business cycle is in contraction ${ }^{14}$. Results are reported in the last 6 columns of Table IV. Considering the results for close polling results first, it is apparent that changes in political uncertainty that occur when polling is particularly close are most important; significance for the non-interaction variables wanes, while $\% \Delta E U$ is highly significant when polling is close. Introducing the interaction term for high levels of economic risk ( $L o_{-} E R R$ ) demonstrates that political uncertainty is also important in this scenario, that is when economic risk is high then changes in political uncertainty (both $\% \Delta I U$ and $\% \Delta E U$ ) have a positive and significant relationship with changes in market uncertainty. Perhaps the most interesting result is found when considering contractions in the business cycle. Consistent with the theoretical model of Pastor and Veronesi (2013), the stage of the business cycle is shown to have a substantial influence on the reported relationship with $\% \Delta E U$ having a highly significant impact on market uncertainty during contractions over and above that found in non-contractionary periods. The

\footnotetext{
${ }^{12}$ The dummy variable is set to 1 if the $2 \mathrm{PP}$ poll result lies in the narrowest quintile of polling margins, and 0 otherwise.

${ }^{13}$ High levels of economic risk are defined as the lowest quintile of ERR; if the observation lies within this quintile the dummy variable is set to 1 and is 0 otherwise. Note that all observations in the lowest quintile of ERR occur during ALP government incumbency and therefore interaction with the L-NP incumbency dummy variable is excluded as this is a linear combination and produces a near singular matrix.

${ }^{14}$ During the sample period the Australian economy did not suffer a recession in the traditional sense. Therefore, contraction is indicated using the growth cycle peak to trough as defined by the Melbourne Institute of Applied Economic and Social Research (http://melbourneinstitute.com/macro/reports/bcchronology.html)
} 
positive and significant coefficient for \% $\% I U \cdot L N P$. Contraction could be explained as the market becoming more concerned (i.e. market uncertainty increasing) if the L-NP incumbent party responsible for the economic policies that have placed the business cycle in contraction has a higher likelihood of re-election.

\subsection{The influence of macroeconomic factors}

It is possible that macroeconomic factors also have a significant influence on market uncertainty and the implied volatility of exchange traded options. Macroeconomic variables are introduced into the model specification in order to examine whether the impact of political uncertainty remains when controlling for economic conditions. A model is specified as follows:

$$
\begin{aligned}
\% \Delta \sigma_{n, t}^{i}=\alpha+ & \beta_{1} \% \Delta I U_{n, t}+\beta_{2} \% \Delta E U_{n, t}+\beta_{3} \% \Delta I U \cdot L N P_{n, t}+\beta_{4} \% \Delta I N F L_{n, t}+\beta_{5} \% \Delta U N E M P_{n, t} \\
& +\beta_{6} \% \Delta A S X_{n, t}+\beta_{7} \% \Delta \operatorname{CONSCONF}_{n, t}+\beta_{8} \% \Delta R B A C R_{n, t}+\beta_{9} \% \Delta A U D T W I_{n, t} \\
& +\beta_{10} \Delta 3 s 10 s_{n, t}+\varepsilon_{n, t}
\end{aligned}
$$

The regression results for Eq. (5) are reported in Table V, Column (1) and (6). Election uncertainty appears to have a positive and significant relationship with market uncertainty, even after controlling for economic variables, although this relationship is much stronger for equity options. A $1 \%$ increase in election uncertainty induces a $0.58 \%$ increase in SPX option volatility, and only a $0.4 \%$ increase in bond option volatility. $\% \Delta I U$ does not have a significant relationship, but the interaction term with L-NP incumbent is negative and well-defined for SPX options; that is, an increase in the possibility of a L-NP incumbent been re-elected decreases stock market uncertainty.

\section{$<$ Insert Table V>}

Note the substantial increase in explanatory power, $\mathrm{R}^{2}$, as a consequence of including the macroeconomic variables. In particular, stock market returns appear to have a large impact on implied volatility. The percentage change in implied volatility of both instruments has a highly significant and negative relationship with changes in the S\&P/ASX 200 Index, i.e. implied volatility falls as the stock market rises; a $1 \%$ rise in the stock market results in a $4.07 \%$ fall in the implied volatility of SPX options and a $0.59 \%$ fall in the implied volatility of 3-yr bond options. Changes in inflation are also found to have a negative relationship with implied volatility and two related explanations exist for this: Firstly, falling inflation will decrease the probability of rate increases by the RBA and hence be positive for asset prices. Secondly, subdued inflation may 
evidence sound economic management by the incumbent government which will increase the possibility of re-election and hence reduce political and economic uncertainty. Given the close relationship between inflation and interest rate movements it is perhaps surprising that the coefficients for the implied volatility of bond options are not well defined. The lagged implied volatility variable remains significant and negative. Columns (2) and (7) act as a form of robustness check for the results such that a composite economic risk rating replaces the macroeconomic variables in the specification of Eq. (5). As ERR decreases (economic risk increases) market uncertainty increase; specifically if ERR increases by $1 \%$ then implied option volatility for SPX options will fall by $0.166 \%$, and YTT options by $0.086 \%$. Using this alternate specification changes the magnitude but not the direction, or significance, of the election uncertainty variables that are of interest.

Again, to understand the conditions under which election uncertainty is most important, and address hypothesis $\mathrm{H}_{3}$, it is necessary to introduce state-variable dummies and interaction terms with the election uncertainty variables. For both equity and bond markets it is apparent that election uncertainty variables have a significant relationship with implied volatility only when the margin within the opinion polls are close; when this is the case $\% \Delta E U$ has a positive and significant relationship with markets, while $\% \Delta I U$ has a significant (negative) relationship with only the equity option market. Incorporating dummy variables for low ERR (i.e. high economic risk) the results, in Columns (4) and (9), suggests that election uncertainty has particular importance in periods of high economic risk; indeed, changes in $\% \Delta I U$ only have significance for the bond market in such periods. Similar results are found when consider periods of business cycle contraction noting that financial market uncertainty increases if the L-NP incumbent party responsible for economic policies during a contraction has a greater chance of re-election (increasing \% $I U \cdot L N P$ ).

As discussed earlier, it is likely that economic conditions will exert an influence on voting behaviour and so, following Goodell and Vähämaa (2013), an orthogonalization procedure is utilized to mitigate concerns related to jointly determined independent variables. Changes in election uncertainty, $\% \Delta E U$, are regressed on lagged control variables that measure changes in macroeconomic factors:

$$
\begin{aligned}
\% \Delta E U_{n, t}=\alpha+ & \beta_{1} \% \Delta I N F L_{n, t-1}+\beta_{2} \% \Delta U N E M P_{n, t-1}+\beta_{3} \% \Delta A S X_{n, t-1}+\beta_{4} \% \Delta \operatorname{CONSCONF}_{n, t-1} \\
& +\beta_{5} \% \Delta R B A C R_{n, t-1}+\beta_{6} \% \Delta A U D T W I_{n, t-1}+\beta_{7} \Delta 3 s 10 s_{n, t-1}+\varepsilon_{n, t}
\end{aligned}
$$


The residual term, $\varepsilon_{n, t}$ of Eq. (6) measures the component of $\% \Delta U E$ that is uncorrelated with the macroeconomic variables. The residuals are employed to isolate the effects of federal elections, from changes in economic conditions, on implied market volatility. \% defined as the residual of Eq. (6) and is utilized in a regression specification where percentage changes in implied volatility are regressed on macroeconomic variables:

$$
\begin{aligned}
\% \Delta \sigma_{n, t}^{i}=\alpha+ & \beta_{1} \% \Delta \operatorname{EURESID}_{n, t}+\beta_{2} \% \Delta \operatorname{INFL}_{n, t}+\beta_{3} \% \Delta U N E M P_{n, t}+\beta_{4} \% \Delta A S X_{n, t} \\
& +\beta_{5} \% \Delta \operatorname{CONSCONF}_{n, t}+\beta_{6} \% \Delta R B A C R_{n, t}+\beta_{7} \% \Delta \operatorname{AUDTWI}_{n, t}+\beta_{8} \Delta 3 s 10 s_{n, t} \\
& +\varepsilon_{n, t}
\end{aligned}
$$

Table VI reports the estimates of the regression specified in Eq. (7). In both cases the coefficient estimates for \% EURESID are positive and statistically significant. These estimates demonstrate that implied volatility increases as election uncertainty increases, and also indicate that the positive association between market uncertainty and political uncertainty cannot be attributed to changes in macroeconomic conditions prompting a reaction in both election polling and implied volatility. The highly significant and negative relationship between stock market returns and implied volatility remains, as does the negative relationship between inflation and implied volatility. Finally, the mean reversion of volatility is again evident in the lagged implied volatility variable.

\section{$<$ Insert Table VI >}

In summary, consistent with $\mathrm{Li}$ and Born (2006) and Bialkowski et al. (2008), the empirical analysis provides strong evidence that election uncertainty has a significant impact on market uncertainty. In addition, the results are analogous to the more general finding of prior work such that important scheduled news events create market uncertainty which is only resolved when the outcome is known. Consistent with hypothesis $\mathrm{H}_{1}$, the election uncertainty measure defined here exhibits a significant and positive relationship with implied volatility. The likelihood of the incumbent remaining in power reduces implied volatility, although this is primarily driven by the interaction with the L-NP Coalition being incumbent. This is consistent with Hypothesis $\mathrm{H}_{2}$ such that the market prefers incumbents where economic policy is known, and a particular preference for the L-NP which is often viewed as more sympathetic towards business.

The introduction of macroeconomic control variables greatly increases the explanatory power of the expression, and in particular there is evidence of a significant negative relationship 
between stock market returns and implied volatility. However, even after controlling for macroeconomic variables and the possibility that economic conditions effect voting intentions, election uncertainty remains a significant factor in determining market uncertainty in both equity and bond markets. Introducing dummy variables for the closeness of opinion polling and the state of the economy reveals additional information as to the circumstances in which election uncertainty is most important in influencing financial market uncertainty. Consistent with Hypothesis $\mathrm{H}_{3}$, market uncertainty appears to be most sensitive to election uncertainty when election uncertainty is highest (when polling is closest), when the business cycle is in contraction, and when the level of economic risk is high. Such results are also supported by Kelly, Pastor and Veronesi (2013) who note that option protection against political risk is more valuable when the economy is weaker.

\subsection{Political Uncertainty and Debt Issuance}

A further consideration in the context of the impact of political uncertainty on Australian financial markets is the understanding of potential effects on changes in the levels of outstanding debt, and related issuance, by both Government and non-Government entities. A regression specification of the following form is used to gain an insight into this relationship:

$$
\% \Delta D e b t_{n, t}^{i}=\alpha+\beta_{1} \% \Delta I U_{n, t}+\beta_{2} \% \Delta E U_{n, t}+\beta_{3} \% \Delta I U \cdot L N P_{n, t}+\beta_{4} \% \Delta E R R_{n, t}+\varepsilon_{n, t}
$$

Where $\% \Delta D e b t_{n, t}^{i}$ is the percentage change in the outstanding amount of debt ${ }^{15}$ of type $i$ (Short-Term or Long-Term, Government and Non-Government) and $\% \Delta E R R_{n, t}$ is the percentage change in the economic risk factor during period $t$, in election $n$. Percentage changes in Election Uncertainty (EU), Incumbent Uncertainty (IU), and the interaction term with the dummy for LNP incumbency (LNP) are specified earlier. Results are reported in Table VII.

$$
<\text { Insert Table VII }>
$$

The first result to note is that the constant term is positive and significant, implying that the level of outstanding debt of all types increases over the sample period. The second point is that changes in ERR have a highly significant relationship with changes in the level of outstanding debt. Recalling that lower ERR implies a higher level of economic risk, the level of outstanding Government debt increases as economic risk increases, while the level of ST debt of

\footnotetext{
${ }^{15}$ Data provided from the Reserve Bank of Australia (www.rba.gov.au )
} 
Non-Government entities declines. Presumably this is a result of debt becoming prohibitively expensive for Non-Government entities at times of high economic risk, and Governments increasing borrowing to fund larger budget deficits. This is also consistent with corporations reducing expenditure during times of economic turmoil.

$\% \triangle E U$ has a negative relationship with outstanding debt levels in all cases; however this is only significant for LT Government debt, where a $1 \%$ increase in election uncertainty is related to a $0.20 \%$ decrease in LT Government debt. The $\% \Delta I U \cdot L-N P$ incumbency interaction term has a dichotomous relationship with Government and Non-Government debt, with LT Government debt increasing as $I U$ increases when L-NP holds power (indicative of L-NP issuing more longterm debt if they appear more likely to remain in power), yet ST Non-Government debt does the opposite.

Upon considering the effect of close polling periods it is apparent at a close polling margin, which is indicative of the highest levels of political uncertainty, result in higher levels of debt for both classes of borrower - perhaps this is a result of alternative types of finance (e.g. equity) becoming more expensive when political uncertainty is highest. The \% incumbency term is negative for LT Government debt when polling is close; it is possible to offer one explanation for this with the observation at incumbent $L-N P$ Governments during the past decade or so have fought electoral campaigns on the basis of claims that they are more prudent economic managers and able to reduce Government debt levels ${ }^{16}$. Low levels of ERR (i.e. periods of high economic risk) are indicative of statistically significant increases in both ST and LT Government debt, while increases in Election Uncertainty ( $E U$ ) have a negative relationship with LT Government debt during such periods. Periods of business cycle contraction do not result in any significant relationship being identified.

Having identified that political uncertainty has a significant relationship with changes in the levels of outstanding debt, particular on those of LT Government debt, it is of particular interest to investigate whether political uncertainty impacts the characteristics of LT Government debt issuance. Data on bond issuance, particularly the dollar amount of bonds allotted, coverage ratio for the issue (defined as dollar amount of bids received divided by the dollar amount of bonds allotted), the average maturity of bonds issued, and the average yield of bonds issued is

\footnotetext{
${ }^{16}$ For example The Federal Coalition Election Policy Commitments suggest that the L-NP will form a "government with less debt and an improved budget bottom line".
} 
obtained from the Australian Office of Financial Management (AOFM). The results for a regression specification similar to that in Eq. (8) with the characteristic of interest replacing outstanding debt levels as the dependent variables are reported in Table VIII.

\section{$<$ Insert Table VIII $>$}

The results may be summarized as follows. First, an increase in election uncertainty $(\% \Delta \mathrm{EU})$ results in a decline in the size of bond issues, a decrease in the demand for the bonds issued (illustrated by the coverage ratio), and an increase in yields; suggesting that political uncertainty plays an important role in the issuance of Long-Term Government bonds. The relationship between $\% \Delta E U$ and the average maturity of bonds issued is driven by the periods of extremely close polling results. Second, increases in the Economic Risk Rating (i.e. reductions in levels of economic risk) result in a significant decrease in the size of bond issues, and an increase in the coverage ratio. Third, the size of bond issues tends to increase as \% $\Delta \mathrm{IU} \cdot \mathrm{LNP}$ increases, although this relationship is reversed on the occasions when polling is close. Lastly, the size of bond issues declines when polling is close.

\section{Conclusion}

This study examines the effects of political uncertainty on the Australian debt and equity markets. Empirical measures of political uncertainty are constructed, using opinion polling data, for five Australian election cycles between 2001 and 2013 in order to investigate three hypotheses, and also to conduct an initial investigation as to the relationship between political uncertainty and debt issuance.

The empirical results indicate that Australian federal election uncertainty has a significant impact on market uncertainty. In particular, the implied volatility of both equity and bond options increases in line with election uncertainty around the outcome of the poll result. Market uncertainty falls as the likelihood of the incumbent winning rises, this is especially so if the L-NP is incumbent. The results are robust to the inclusion of macroeconomic control variables, and are consistent with the notion that the Australian federal election process may result in fluctuating levels of uncertainty among market participants as they revise their expectations regarding the future direction of economic policy. Such results are consistent with the work on the U.S. Presidential election stated by Goodell and Vähämaa (2013) and suggest that election uncertainty has an influence on financial markets regardless of the electoral system in place. The theoretical 
model of Pastor and Veronesi (2013) proposes that political uncertainty is state-dependent and most important during economic contractions. In light of this model, the introduction of dummy variables to control for the economic cycle, and the closeness of opinion polling, reveal that Australian financial markets appear to be most sensitive to political uncertainty when election uncertainty is highest (polling is close), when the business cycle is contracting and the level of economic risk is high.

With polling regularity and political scrutiny increasing during the period surrounding elections, the results presented in this article provide strong evidence that market participants are likely to be effected by the level of political uncertainty. One policy implication that arises from the results in this paper would be that political parties may reduce uncertainty in financial markets by flagging their economic policies well in advance; of course, this would not make a difference if market participants did not believe such polices would actually be implemented or sustained in the event of an election win.

Whilst this paper has contributed to the evidence of the ways in which political uncertainty influences financial market uncertainty, and made an effort to investigate how this feeds through to the level, and issuance, of debt there are several areas of further research that would appear worth of consideration. Firstly, gaining a greater understanding of the mechanism by which Government debt issues are affected would be of interest to both Governments and potential bidders at debt auctions. Second, greater focus could be given to the issues that corporations face when attempting to raise funds (whether through debt or equity) in times of political uncertainty. For instance, what are the effects of political uncertainty on access to markets, and the relative cost of issuing debt and equity? Perhaps some industries would be more susceptible to political uncertainty in terms of both capital raising, and implied volatility measures, that others? Finally, it may be possible to utilise information from betting markets, such as betmetrix $\mathbf{x}^{17}$ in order to understand the dynamics of election and market uncertainty at a higher frequency.

\section{References}

Bialkowski, J., K. Gottschalk, T.P. Wisniewski, 2008, Stock market volatility around national elections, Journal of Banking and Finance, 32, 1941-1953

\footnotetext{
${ }^{17}$ www.betmetrix.com
} 
Cassette, A., and E. Farvaque, 2014, Are elections debt brakes? Evidence from French municipalities, Economics Letters, 122, 314-316

Chen, E.T., and A. Clements, 2007, S\&P 500 implied volatility and monetary policy announcements, Finance Research Letters, 4, 227-232

Drazen, A., and M. Eslava, 2010, Electoral manipulation via voter-friendly spending: Theory and evidence, Journal of Development Economics, 92, 39-52

Ederington, L.H. and J.H. Lee, 1996, The creation and resolution of market uncertainty: The impact of information releases on implied volatility, Journal of Financial and Quantitative Analysis, 31, 513-539

Frijns, B., C. Tallau, A. Tourani-Rad, 2010, The information content of implied volatility: Evidence from Australia, Journal of Futures Markets, 2010, 30, 134-155

Gao, P., and Y. Qi, 2013, Political uncertainty and public financing costs: Evidence from U.S. gubernatiorial elections and municipal bond markets, Working Paper, University of Notre Dame

Gemmill, G., 1992, Political risk and market efficiency: Tests based in British stock and options markets in the 1987 election, Journal of Banking and Finance, 16, 211-231

Goodell, J.W., and S. Vähämaa, 2013, US presidential elections and implied volatility: The role of political uncertainty, Journal of Banking and Finance, 27, 1108-1117

Hibbs, D., 1986, Political parties and macroeconomic policies and outcomes in the United States, American Economic Review, 66-70

Julio, B., and Y. Yook, 2012, Political uncertainty and corporate investment cycles, Journal of Finance, 67, 45-83

Johnson, R.R., W. Chittenden, and G. Jensen, 1999, Presidential politics, stocks, bonds, bills, and inflation, Journal of Portfolio Management, 26, 27-31

Kelly, B., L. Pastor, and P. Veronesi, 2013, The price of political uncertainty: Theory and evidence from the option market, Working Paper, University of Chicago

Li, J., J.A. Born, 2006, Presidential election uncertainty and common stock returns in the United States, Journal of Financial Research, 29, 609-622

Nikkinen, J., and P. Sahlström, 2004, Impact of the Federal Open Market Committee's meetings and scheduled macroeconomic news on stock market uncertainty, International Review of Financial Analysis, 13, 1-12

Pantzalis, C., D.A. Strangeland, and H.J. Turtle, 2000, Political elections and the resolution of uncertainty: the international evidence, Journal of Banking and Finance, 24, 1575-1604 
Pastor, L., and P. Veronesi, 2012, Uncertainty about Government policy and stock prices, Journal of Finance, 67, 1219-1264

Pastor, L., and P. Veronesi, 2013, Political uncertainty and risk premia, Journal of Financial Economics, 110, 520-545

Rhode, P.W., and K.S. Strumpf, 2004, Historical Presidential betting markets, Journal of Economic Perspectives, 18, 127-142

Smales, L.A., 2013, Impact of macroeconomic announcements on interest rate futures: Highfrequency evidence from Australia, Journal of Financial Research, 36, 371-388

Vähämaa, S., S. Watzka, and J. Äijö, 2005, What moves option-implied bond market expectations, Journal of Futures Markets, 25, 817-843

Vähämaa, S., and J. Äijö, 2011, The Fed's policy decisions and implied volatility, Journal of Futures Markets, 31, 995-1009

Veiga, L.G., and F.J. Veiga, 2007, Does opportunism pay-off? Economics Letters, 96, 177-182 
Figure 1

Panel A: Polling results - 2 party preferred polling for Australian federal election

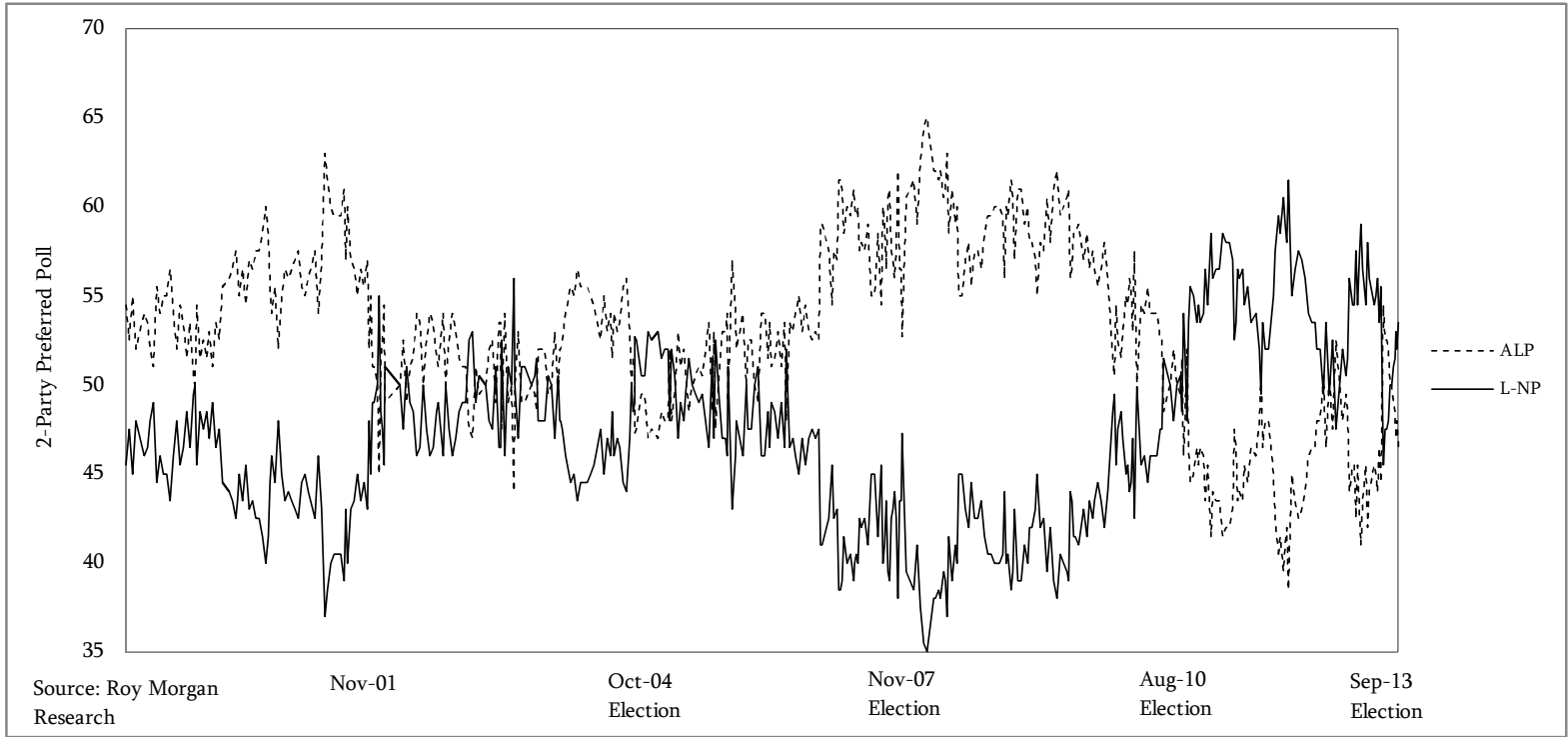

Panel B: (Re-based) Implied volatility of Australian equity and bond markets

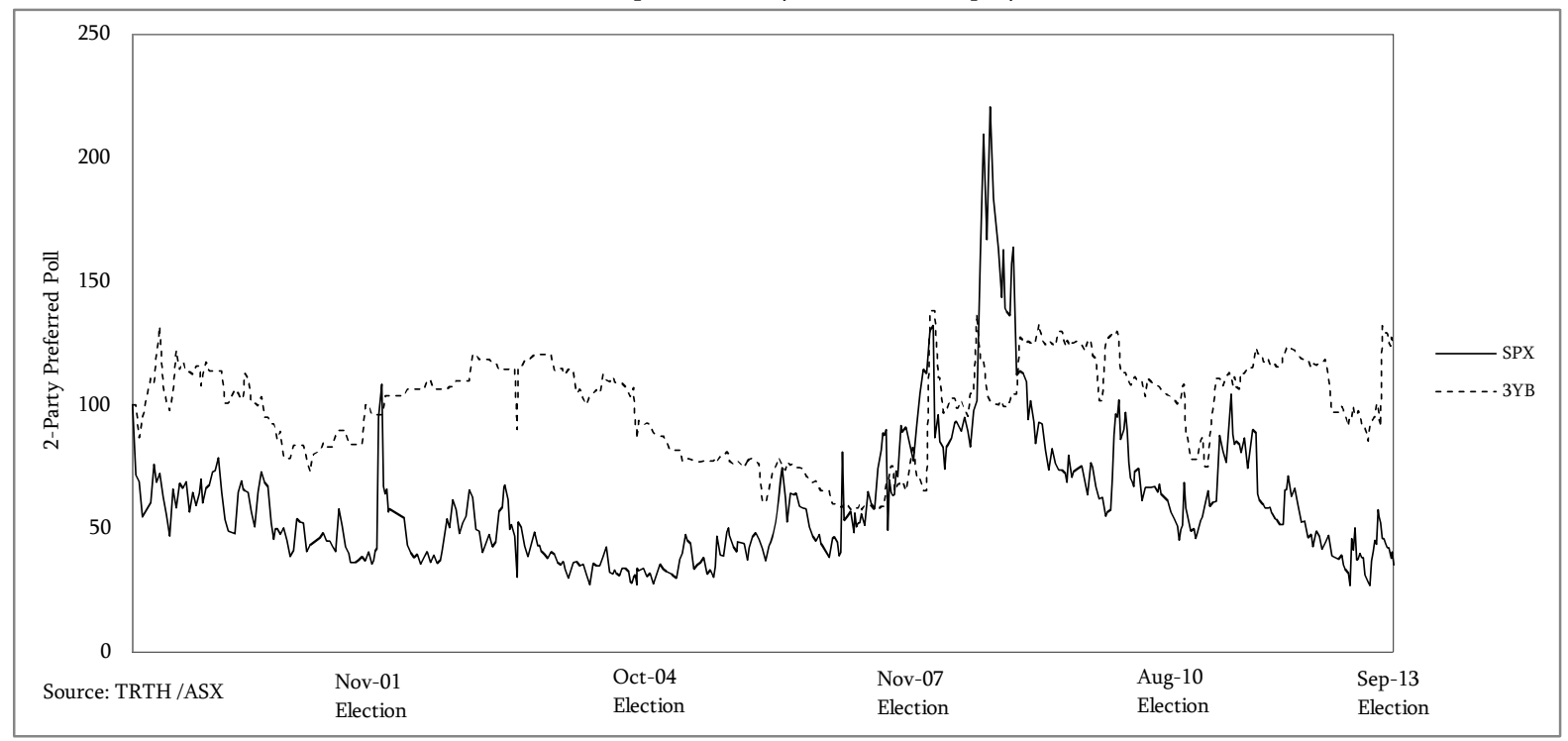


TABLE I

Summary Statistics for implied volatility, political and macroeconomic variables

\begin{tabular}{|c|c|c|c|c|c|c|c|c|c|c|c|c|}
\hline & \multicolumn{2}{|c|}{2001 Election } & \multicolumn{2}{|c|}{2004 Election } & \multicolumn{2}{|c|}{2007 Election } & \multicolumn{2}{|c|}{2010 Election } & \multicolumn{2}{|c|}{2013 Election } & \multicolumn{2}{|c|}{ Overall } \\
\hline & Mean & Std Dev & Mean & Std Dev & Mean & Std Dev & Mean & Std Dev & Mean & Std Dev & Mean & Std Dev \\
\hline$\% \Delta \sigma_{\mathrm{SPX}}$ & 0.10 & 22.97 & -0.44 & 11.43 & 2.13 & 12.67 & -0.30 & 12.11 & -2.06 & 16.10 & -0.16 & 13.23 \\
\hline$\% \Delta \sigma_{3 \mathrm{YB}}$ & 1.07 & 4.14 & -0.59 & 8.97 & 1.37 & 9.41 & -0.97 & 5.20 & 0.22 & 8.00 & 0.10 & 7.56 \\
\hline$\% \Delta \mathrm{IU}$ & 0.21 & 7.90 & 0.28 & 3.85 & 0.02 & 7.25 & -0.17 & 4.87 & 0.32 & 8.79 & 0.08 & 6.06 \\
\hline$\% \Delta \mathrm{EU}$ & 0.41 & 5.84 & -0.03 & 3.34 & 0.02 & 7.25 & 0.44 & 6.50 & -0.22 & 4.10 & 0.21 & 5.84 \\
\hline$\% \Delta \mathrm{INFL}$ & 0.27 & 1.53 & -0.07 & 0.38 & -0.44 & 0.26 & 0.16 & 0.75 & 0.14 & 0.38 & -0.02 & 0.73 \\
\hline$\% \Delta \mathrm{UNEMP}$ & 0.36 & 2.12 & -0.69 & 2.69 & -0.78 & 2.22 & -0.98 & 1.92 & 0.55 & 2.43 & -0.52 & 2.24 \\
\hline$\% \triangle \mathrm{ASX}$ & 0.18 & 2.81 & 0.43 & 1.36 & 0.60 & 2.20 & 0.28 & 3.20 & 0.58 & 2.23 & 0.37 & 2.39 \\
\hline$\% \triangle \mathrm{CONSCONF}$ & -0.75 & 6.08 & 0.14 & 2.63 & -0.38 & 5.37 & 1.32 & 5.60 & -0.19 & 4.43 & 0.08 & 4.92 \\
\hline$\% \triangle \mathrm{RBACR}$ & -1.27 & 2.37 & 0.32 & 1.40 & 0.40 & 1.19 & 1.31 & 3.32 & -1.01 & 2.26 & 0.19 & 2.07 \\
\hline$\% \Delta$ AUDTWI & 0.18 & 2.19 & 0.22 & 1.63 & 0.24 & 1.87 & 0.22 & 1.92 & -0.33 & 1.58 & 0.22 & 1.90 \\
\hline$\Delta 3 \mathrm{~s} 10 \mathrm{~s}$ & 0.04 & 0.19 & -0.17 & 0.12 & -0.03 & 0.16 & -0.07 & 0.19 & 0.06 & 0.20 & -0.06 & 0.16 \\
\hline$\% \Delta \mathrm{ERR}$ & -0.04 & 1.23 & 0.04 & 0.22 & -0.08 & 0.43 & 0.09 & 0.49 & 0.33 & 1.65 & 0.07 & 0.80 \\
\hline Number of obs. & \multicolumn{2}{|c|}{29} & \multicolumn{2}{|c|}{32} & \multicolumn{2}{|c|}{31} & \multicolumn{2}{|c|}{32} & \multicolumn{2}{|c|}{32} & \multicolumn{2}{|c|}{156} \\
\hline
\end{tabular}


TABLE II

Correlations for implied volatility, political and macroeconomic variables

\begin{tabular}{|c|c|c|c|c|c|c|c|c|c|c|}
\hline & $\% \Delta \sigma_{\mathrm{SPX}}$ & $\% \Delta \sigma_{3 \mathrm{YB}}$ & $\% \Delta \mathrm{IU}$ & $\% \Delta \mathrm{EU}$ & $\% \Delta \mathrm{INFL}$ & $\% \Delta \mathrm{UNEMP}$ & $\% \Delta \mathrm{ASX}$ & $\% \triangle \mathrm{RBACR}$ & $\% \triangle \mathrm{CONSCONF}$ & $\% \triangle$ AUDTWI \\
\hline$\% \Delta \sigma_{3 \mathrm{YB}}$ & 0.273 & & & & & & & & & \\
\hline$\% \Delta \mathrm{IU}$ & -0.134 & -0.073 & & & & & & & & \\
\hline$\% \Delta \mathrm{EU}$ & 0.240 & 0.030 & 0.207 & & & & & & & \\
\hline$\% \Delta \mathrm{INFL}$ & -0.091 & -0.101 & 0.081 & 0.028 & & & & & & \\
\hline$\% \Delta \mathrm{UNEMP}$ & 0.034 & -0.122 & -0.067 & -0.001 & -0.136 & & & & & \\
\hline$\% \Delta \mathrm{ASX}$ & -0.779 & -0.222 & 0.145 & -0.252 & -0.045 & -0.027 & & & & \\
\hline$\% \triangle \mathrm{RBACR}$ & 0.123 & -0.028 & -0.079 & -0.020 & 0.376 & -0.103 & -0.129 & & & \\
\hline$\% \Delta \mathrm{CONSCONF}$ & 0.077 & -0.011 & 0.083 & 0.083 & 0.160 & -0.165 & 0.129 & 0.146 & & \\
\hline$\% \Delta$ AUDTWI & 0.168 & 0.024 & 0.008 & 0.082 & 0.145 & -0.042 & -0.114 & 0.022 & 0.302 & \\
\hline$\Delta 3 \mathrm{~s} 10 \mathrm{~s}$ & 0.320 & 0.033 & -0.202 & 0.207 & -0.093 & -0.007 & -0.291 & 0.092 & -0.150 & -0.042 \\
\hline
\end{tabular}

Note: This table reports the cross-correlations for the variables included within the empirical anaysis of this paper. Variables include the percentage change of implied volatility of SPX equity options and 3-yr government bond options. In addition, the percentage change in measures of political uncertainty (IU and EU) and a range of macroeconomic control variables including inflation, unemployment, consumer confidence, the RBA cash rate, and the AUD trade-weighted index are included. 
TABLE III

Base regression: Influence of political uncertainty on market uncertainty

\begin{tabular}{|c|c|c|c|c|c|c|c|c|c|c|c|c|}
\hline \multirow[b]{2}{*}{ Variable } & \multicolumn{6}{|c|}{$\% \Delta \sigma_{S P X}$} & \multicolumn{6}{|c|}{$\% \Delta \sigma_{3 \curlyvee B}$} \\
\hline & 2001 & 2004 & 2007 & 2010 & 2013 & Model 1 & 2001 & 2004 & 2007 & 2010 & 2013 & Model 1 \\
\hline \multirow[t]{2}{*}{ Constant } & 0.127 & -1.140 & 1.737 & -0.575 & -2.091 & 0.246 & 0.389 & -0.568 & 1.387 & -0.948 & 0.347 & 0.054 \\
\hline & (3.722) & $(1.487)$ & $(2.142)$ & $(2.321)$ & (2.749) & (1.336) & $(0.486)$ & (1.301) & (1.507) & $(0.979)$ & (1.383) & $(0.611)$ \\
\hline \multirow[t]{2}{*}{$\% \Delta I U$} & $-1.220^{* *}$ & $-1.808^{*}$ & -0.248 & -0.047 & -0.041 & $-0.528^{* *}$ & -0.045 & -0.003 & -0.010 & -0.319 & -0.312 & -0.131 \\
\hline & $(0.586)$ & $(1.032)$ & $(0.332)$ & $(1.731)$ & $(0.544)$ & $(0.241)$ & $(0.074)$ & $(0.847)$ & $(0.257)$ & $(0.750)$ & $(0.268)$ & $(0.130)$ \\
\hline \multirow[t]{2}{*}{$\% \Delta E U$} & $2.122^{* *}$ & $1.102^{* *}$ & $0.252^{*}$ & $0.602^{* *}$ & $1.533^{* *}$ & $0.832^{* * *}$ & $0.715^{* * *}$ & $0.445^{* *}$ & $0.322^{* *}$ & $0.186^{*}$ & $0.564^{*}$ & $0.158^{* *}$ \\
\hline & $(0.830)$ & $(0.502)$ & $(0.148)$ & $(0.242)$ & (0.709) & $(0.255)$ & $(0.140)$ & $(0.197)$ & $(0.156)$ & $(0.106)$ & $(0.308)$ & $(0.074)$ \\
\hline \multirow[t]{2}{*}{$A R(1)$} & $-0.200^{*}$ & $-0.299^{*}$ & $-0.096^{*}$ & -0.084 & -0.188 & $-0.045^{* * *}$ & $-0.592^{* *}$ & $-0.229^{*}$ & $-0.182^{*}$ & 0.004 & 0.002 & $-0.227^{* *}$ \\
\hline & $(0.108)$ & $(0.173)$ & $(0.049)$ & $(0.199)$ & $(0.181)$ & $(0.010)$ & $(0.265)$ & $(0.127)$ & $(0.106)$ & $(0.179)$ & $(0.175)$ & $(0.098)$ \\
\hline Fixed or random & - & - & - & - & - & Fixed & - & - & - & - & - & Fixed \\
\hline adj. $\mathrm{R}^{2}$ & 0.293 & 0.214 & 0.209 & 0.115 & 0.138 & 0.186 & 0.740 & 0.212 & 0.132 & 0.019 & 0.082 & 0.082 \\
\hline F-Stat & 2.904 & 2.393 & 1.902 & 1.218 & 2.603 & 2.547 & 10.433 & 1.178 & 0.452 & 0.087 & 1.483 & 1.483 \\
\hline No. Obs & 29 & 32 & 31 & 32 & 32 & 156 & 26 & 32 & 31 & 32 & 32 & 153 \\
\hline
\end{tabular}

Note: This table presents results from the base regression set out in Eq. (3) whereby the percentage change in implied volatility of SPX equity options, and 3-yr bond options, are regressed on the percentage change in the two identified political uncertainty variables (Incumbent Uncertainty, IU, and Election Uncertainty, EU) as well as one-lagged term of the dependent variable. A simple linear OLS is used to disaggregate into individual election cycles, while a panel based model (with fixed time effects) is utilized to analyze the overall effect. Standard errors reported in parentheses. ${ }^{* * *},{ }^{* *},{ }^{*}$ denote significance at the $1 \%, 5 \%$, and $10 \%$ levels respectively. 
TABLE IV

Regression: Influence of political party of incumbent Prime Minister

\begin{tabular}{|c|c|c|c|c|c|c|c|c|}
\hline \multirow[b]{2}{*}{ Variable } & \multicolumn{2}{|c|}{ Un-Conditioned } & \multicolumn{6}{|c|}{ Conditioned on dummy state-variables } \\
\hline & $\% \Delta \sigma_{S P X}$ & $\% \Delta \sigma_{3 Y B}$ & $\% \Delta \sigma_{S P X}$ & $\% \Delta \sigma_{S P X}$ & $\% \Delta \sigma_{S P X}$ & $\% \Delta \sigma_{3 Y B}$ & $\% \Delta \sigma_{3 Y B}$ & $\% \Delta \sigma_{3 Y B}$ \\
\hline \multirow{2}{*}{ Constant } & 0.301 & 0.059 & 0.634 & 0.004 & 0.126 & 0.066 & 0.276 & 0.279 \\
\hline & $(1.248)$ & $(0.613)$ & $(1.288)$ & $(1.146)$ & $(1.134)$ & $(0.846)$ & $(0.718)$ & $(0.727)$ \\
\hline \multirow[t]{2}{*}{$\% \Delta I U$} & 1.158 & 0.043 & 0.256 & 0.972 & 1.278 & 0.137 & 0.173 & 0.109 \\
\hline & $(0.756)$ & $(0.392)$ & $(0.385)$ & $(0.546)$ & $(1.075)$ & $(0.243)$ & $(0.331)$ & $(0.669)$ \\
\hline \multirow[t]{2}{*}{$\% \triangle E U$} & $1.496^{* * *}$ & $0.173^{* *}$ & 0.194 & 1.407 & $1.585^{* * *}$ & 0.113 & 0.125 & $0.191^{* *}$ \\
\hline & $(0.377)$ & $(0.087)$ & $(0.285)$ & $(0.332)$ & $(0.349)$ & $(0.183)$ & $(0.197)$ & $(0.072)$ \\
\hline \multirow[t]{2}{*}{$\% \Delta I U \cdot L N P$} & $-2.216^{* *}$ & -0.226 & -0.394 & -0.044 & $-2.464^{* *}$ & -0.256 & -0.317 & $-0.289^{* *}$ \\
\hline & $(0.944)$ & $(0.480)$ & $(0.461)$ & $(0.546)$ & $(1.204)$ & $(0.292)$ & $(0.337)$ & $(0.107)$ \\
\hline \multirow[t]{2}{*}{$A R(1)$} & $-0.197^{* *}$ & $-0.227^{* *}$ & $-0.063^{*}$ & $-0.086^{*}$ & $-0.079^{*}$ & $-0.143^{*}$ & $-0.144^{*}$ & $-0.140^{*}$ \\
\hline & $(0.098)$ & $(0.099)$ & $(0.036)$ & $(0.045)$ & $(0.046)$ & $(0.079)$ & $(0.079)$ & $(0.071)$ \\
\hline \multirow{2}{*}{ Close_Poll } & & & 2.677 & & & 1.232 & & \\
\hline & & & $(3.388)$ & & & $(2.092)$ & & \\
\hline \multirow[t]{2}{*}{$\% \Delta I U \cdot C l o s e \_P o l l$} & & & -0.069 & & & -0.113 & & \\
\hline & & & $(0.752)$ & & & $(0.290)$ & & \\
\hline \multirow[t]{2}{*}{$\% \Delta E U \cdot C l o s e \_P o l l$} & & & $2.069^{* * *}$ & & & $0.147^{* * *}$ & & \\
\hline & & & $(0.653)$ & & & $(0.041)$ & & \\
\hline \multirow[t]{2}{*}{$\% \Delta I U \cdot L N P \cdot C l o s e \_P o l l$} & & & $-1.751^{*}$ & & & $-1.533^{*}$ & & \\
\hline & & & $(0.972)$ & & & $(0.792)$ & & \\
\hline \multirow[t]{2}{*}{$L o w_{-} E R R$} & & & & 0.103 & & & 0.536 & \\
\hline & & & & $(8.931)$ & & & $(5.449)$ & \\
\hline \multirow[t]{2}{*}{$\% \Delta I U \cdot L o W_{-} E R R$} & & & & $1.901^{* *}$ & & & $0.180^{* *}$ & \\
\hline & & & & $(0.959)$ & & & $(0.078)$ & \\
\hline \multirow[t]{2}{*}{$\% \Delta E U \cdot L o w_{-} E R R$} & & & & $1.463^{* *}$ & & & $0.084^{* *}$ & \\
\hline & & & & $(0.712)$ & & & $(0.403)$ & \\
\hline \multirow[t]{2}{*}{ Contraction } & & & & & 0.964 & & & 1.037 \\
\hline & & & & & $(3.248)$ & & & $(2.215)$ \\
\hline \multirow[t]{2}{*}{$\% \Delta I U \cdot$ Contraction } & & & & & -1.480 & & & -0.001 \\
\hline & & & & & $(1.141)$ & & & $(0.712)$ \\
\hline \multirow[t]{2}{*}{$\% \Delta E U \cdot$ Contraction } & & & & & $1.382^{* * *}$ & & & $0.064^{* *}$ \\
\hline & & & & & $(0.516)$ & & & $(0.316)$ \\
\hline \multirow[t]{2}{*}{$\% \Delta I U \cdot L N P \cdot$ Contraction } & & & & & $3.389^{* *}$ & & & $0.076^{* *}$ \\
\hline & & & & & $(1.518)$ & & & $(0.031)$ \\
\hline \multirow{2}{*}{$\begin{array}{l}\text { Fixed or random } \\
\text { adj. } \mathrm{R}^{2}\end{array}$} & Fixed & Fixed & Fixed & Fixed & Fixed & Fixed & Fixed & Fixed \\
\hline & 0.250 & 0.085 & 0.215 & 0.140 & 0.166 & 0.052 & 0.049 & 0.059 \\
\hline \multirow{2}{*}{$\begin{array}{l}\text { F-Stat } \\
\text { DW }\end{array}$} & 2.727 & 1.923 & 3.051 & 2.205 & 2.442 & 2.629 & 2.721 & 2.582 \\
\hline & 2.084 & 2.135 & 2.095 & 2.083 & 2.113 & 2.126 & 2.132 & 2.131 \\
\hline \multirow{2}{*}{$\frac{\text { No. Obs }}{\text { Note: } 11}$} & 156 & 153 & 156 & 156 & 156 & 153 & 153 & 153 \\
\hline & cesults from & regression & out in Eq. & 4) whereb & the percer & e change & implied v & Tatility of \\
\hline SPX equity options, and 3 & yr bond op & is, are regre & $\mathrm{d}$ on the pe & centage cl & ange in the & ee identific & d political & ancertainty \\
\hline Uncertainty and the incur & nbent Prim & inisiter bee & member of & the LNP C & oalition) as & l as one-la & ged term o & the \\
\hline dependent variable. Indica & itors for clo & olling resu & $\begin{array}{l}\text { member of } \\
\text { the narrow }\end{array}$ & est quintile & $\begin{array}{l}\text { Dalltion) as } \\
\text { of poll resu }\end{array}$ & high econ & $\begin{array}{l}\text { ged term o } \\
\text { omic risk fa }\end{array}$ & ctors \\
\hline (defined as low ERR), and & business cy & contractior & also incl & led. A fixe & time effec & anel speci & cation is $\mathrm{u}$ & \\
\hline Standard errors in parenth & eses. & & & & & & & \\
\hline & & & & & & & & \\
\hline
\end{tabular}


TABLE V

Regression: The influence of macroeconomic variables and political uncertainty on implied volatility

\begin{tabular}{|c|c|c|c|c|c|c|c|c|c|c|}
\hline \multirow[b]{2}{*}{ Variable } & \multicolumn{5}{|c|}{$\% \Delta \sigma_{S P X}$} & \multicolumn{5}{|c|}{$\% \Delta \sigma_{3 Y B}$} \\
\hline & (1) & (2) & (3) & (4) & (5) & (6) & (7) & (8) & (9) & (10) \\
\hline \multirow[t]{2}{*}{ Constant } & 1.182 & 0.078 & 1.335 & 0.457 & 0.484 & 0.157 & 0.271 & 0.452 & 0.390 & 0.397 \\
\hline & $(0.802)$ & $(1.148)$ & $(1.213)$ & $(1.220)$ & (1.219) & $(0.726)$ & $(0.718)$ & $(0.812)$ & $(0.784)$ & $(0.789)$ \\
\hline \multirow[t]{2}{*}{$\% \Delta I U$} & $0.863^{*}$ & 0.111 & 0.418 & 0.766 & $1.854^{*}$ & -0.049 & 0.088 & 0.183 & 0.202 & 0.381 \\
\hline & $(0.487)$ & $(0.372)$ & $(0.387)$ & $(0.559)$ & (1.119) & $(0.412)$ & $(0.225)$ & $(0.246)$ & $(0.346)$ & $(0.694)$ \\
\hline \multirow[t]{2}{*}{$\% \triangle E U$} & $0.575^{* *}$ & $0.925^{* * *}$ & 0.251 & $1.299^{* * *}$ & $1.413^{* * *}$ & $0.036^{* *}$ & $0.116^{* *}$ & 0.148 & $0.170^{* *}$ & $0.178^{* *}$ \\
\hline & $(0.252)$ & $(0.246)$ & $(0.295)$ & $(0.345)$ & $(0.361)$ & $(0.018)$ & $(0.051)$ & $(0.119)$ & $(0.067)$ & $(0.082)$ \\
\hline \multirow[t]{2}{*}{$\% \Delta I U \cdot L N P$} & $-1.160^{* *}$ & $-0.646^{* *}$ & $-0.435^{*}$ & $-0.102^{* *}$ & $-2.871^{* *}$ & -0.031 & -0.247 & -0.328 & -0.365 & -0.564 \\
\hline & $(0.518)$ & $(0.279)$ & $(0.247)$ & $(0.045)$ & $(1.242)$ & $(0.522)$ & $(0.291)$ & $(0.297)$ & $(0.344)$ & $(0.771)$ \\
\hline \multirow[t]{2}{*}{$\% \triangle I N F L$} & $-0.067^{* *}$ & & $-0.015^{* *}$ & $-0.040^{* *}$ & $-0.030^{* *}$ & $-0.020^{*}$ & & $-0.016^{*}$ & $-0.018^{*}$ & $-0.015^{*}$ \\
\hline & $(0.031)$ & & $(0.039)$ & $(0.040)$ & $(0.040)$ & $(0.011)$ & & $(0.010)$ & $(0.011)$ & $(0.009)$ \\
\hline \multirow[t]{2}{*}{$\% \triangle U N E M P$} & 0.096 & & 0.005 & -0.031 & -0.038 & -0.110 & & -0.224 & -0.220 & -0.229 \\
\hline & $(0.161)$ & & $(0.207)$ & $(0.214)$ & $(0.214)$ & $(0.138)$ & & $(0.137)$ & $(0.138)$ & $(0.139)$ \\
\hline \multirow{2}{*}{$\% \triangle A S X$} & $-4.066^{* * *}$ & & $-4.121^{* * *}$ & $-4.080^{* * *}$ & $-4.048^{* * *}$ & $-0.590^{* *}$ & & $-0.598^{* *}$ & $-0.595^{* *}$ & $-0.521^{*}$ \\
\hline & $(0.336)$ & & $(0.439)$ & $(0.451)$ & $(0.454)$ & $(0.294)$ & & $(0.285)$ & $(0.284)$ & $(0.289)$ \\
\hline \multirow[t]{2}{*}{$\% \triangle R B A C R$} & 0.111 & & 0.259 & 0.336 & 0.262 & 0.014 & & 0.380 & 0.390 & 0.383 \\
\hline & $(0.320)$ & & $(0.383)$ & $(0.400)$ & $(0.393)$ & $(0.285)$ & & $(0.254)$ & $(0.257)$ & $(0.256)$ \\
\hline \multirow[t]{2}{*}{$\% \triangle C O N S C O N F$} & 0.040 & & 0.037 & 0.153 & 0.174 & -0.003 & & 0.168 & 0.162 & 0.176 \\
\hline & $(0.177)$ & & $(0.255)$ & $(0.266)$ & $(0.263)$ & $(0.151)$ & & $(0.171)$ & $(0.172)$ & $(0.172)$ \\
\hline \multirow[t]{2}{*}{$\% \triangle A U D T W I$} & 0.317 & & 0.446 & 0.302 & 0.261 & -0.039 & & 0.140 & 0.124 & 0.152 \\
\hline & $(0.318)$ & & $(0.537)$ & $(0.561)$ & $(0.555)$ & $(0.273)$ & & $(0.363)$ & $(0.367)$ & $(0.368)$ \\
\hline \multirow[t]{2}{*}{$43 s 10 \mathrm{~s}$} & 11.953 & & 14.540 & 16.386 & 17.319 & -2.721 & & -4.813 & -4.495 & -5.806 \\
\hline & (11.305) & & $(14.890)$ & (15.496) & $(15.863)$ & $(9.646)$ & & $(9.680)$ & $(9.770)$ & 10.11 \\
\hline \multirow{2}{*}{$\% \Delta E R R$} & & $-0.166^{* * *}$ & & & & & $-0.086^{* *}$ & & & \\
\hline & & $(0.055)$ & & & & & $(0.034)$ & & & \\
\hline \multirow[t]{2}{*}{$A R(1)$} & $-0.158^{*}$ & $-0.158^{*}$ & $-0.115^{*}$ & $-0.125^{*}$ & $-0.115^{*}$ & $-0.122^{*}$ & $-0.143^{*}$ & $-0.123^{*}$ & $-0.126^{*}$ & $-0.126^{*}$ \\
\hline & $(0.092)$ & $(0.080)$ & $(0.059)$ & $(0.073)$ & $(0.062)$ & $(0.065)$ & $(0.078)$ & $(0.071)$ & $(0.071)$ & $(0.073)$ \\
\hline Close_Poll & & & 3.032 & & & & & 1.807 & & \\
\hline & & & (3.438) & & & & & $(2.168)$ & & \\
\hline$\% \Delta I U \cdot C l o s e \_P o l l$ & & & $-1.125^{* *}$ & & & & & -0.037 & & \\
\hline & & & $(0.469)$ & & & & & $(0.301)$ & & \\
\hline$\% \Delta E U \cdot C l o s e \_P o l l$ & & & $1.655^{* * *}$ & & & & & $0.071^{* *}$ & & \\
\hline & & & $(0.562)$ & & & & & $(0.034)$ & & \\
\hline$\% \Delta I U \cdot L N P \cdot C l o s e \_P o l l$ & & & $-1.674^{*}$ & & & & & $-1.191^{*}$ & & \\
\hline & & & $(0.995)$ & & & & & $(0.645)$ & & \\
\hline Low_ERR & & & & 4.607 & & & & & 1.125 & \\
\hline & & & & $(9.830)$ & & & & & $(6.149)$ & \\
\hline$\% \Delta I U \cdot L O W_{-} E R R$ & & & & $1.909^{* *}$ & & & & & $0.299^{* *}$ & \\
\hline & & & & $(0.908)$ & & & & & $(0.137)$ & \\
\hline$\% \Delta E U \cdot L o W_{-} E R R$ & & & & $-1.378^{* *}$ & & & & & $-0.189^{*}$ & \\
\hline & & & & $(0.672)$ & & & & & $(0.077)$ & \\
\hline Contraction & & & & & 0.394 & & & & & 1.188 \\
\hline & & & & & (2.298) & & & & & $(2.358)$ \\
\hline$\% \Delta I U \cdot$ Contraction & & & & & $-1.962^{*}$ & & & & & $-0.240^{*}$ \\
\hline & & & & & $(1.176)$ & & & & & $(0.137)$ \\
\hline$\% \Delta E U \cdot$ Contraction & & & & & $1.111^{* *}$ & & & & & $0.019^{* *}$ \\
\hline & & & & & $(0.532)$ & & & & & $(0.009)$ \\
\hline$\% \Delta I U \cdot L N P \cdot$ Contraction & & & & & $3.763^{* *}$ & & & & & $0.433^{* *}$ \\
\hline & & & & & $(1.574)$ & & & & & $(0.203)$ \\
\hline Fixed/Random & Fixed & Fixed & Fixed & Fixed & Fixed & Fixed & Fixed & Fixed & Fixed & Fixed \\
\hline adj. $R^{2}$ & 0.684 & 0.615 & 0.749 & 0.699 & 0.718 & 0.138 & 0.115 & 0.150 & 0.143 & 0.143 \\
\hline F-Stat & 5.601 & 4.978 & 2.520 & 3.890 & 2.982 & 3.041 & 2.724 & 2.919 & 2.800 & 2.759 \\
\hline DW & 2.078 & 2.100 & 2.097 & 2.121 & 2.129 & 2.069 & 2.129 & 2.214 & 2.221 & 2.226 \\
\hline No. Obs & 148 & 148 & 148 & 148 & 148 & 138 & 138 & 138 & 138 & 138 \\
\hline
\end{tabular}

Note: This table presents results from the regression set out in Eq. (5) whereby the percentage change in implied volatility of SPX equity options, and 3-yr bond options, are regressed on the percentage change in the three identified political uncertainty variables (Incumbent Uncertainty, IU, and Election Uncertainty, EU, and an interaction term between Incumbent Uncertainty and the incumbent Prime Minister been a member of the LNP Coalition), one-lagged term of the dependent variable, and on a number of control variables for macroeconomic variables. Economic variables are the percentage change in inflation (INFL), unemployment (UNEMP), the stock market ( $A S X$ ), the RBA cash rate $(R B A C R)$, consumer confidence (CONSCONF), and A $\$$ trade weighted index ( $A U D T W I)$. The change in the level of the yield curve slope measure by the difference between 10yr and 3-yr government bond yields is also included ( $3 \mathrm{~s} 10 \mathrm{~s}$ ). Indicators for close polling results (the narrowest quintile of poll results), high economic risk factors (defined as low ERR), and business cycle contraction are also included. A fixed time effects panel specification is used. Standard errors in parentheses. ${ }^{* * *},{ }^{* *},{ }^{*}$ denote significance at the $1 \%, 5 \%$, and $10 \%$ levels respectively. 
TABLE VI

Regression: Robustness check when controlling for orthogonalized changes in election uncertainty

\begin{tabular}{|c|c|c|}
\hline Variable & $\% \Delta \sigma_{S P X}$ & $\% \Delta \sigma_{3 Y B}$ \\
\hline \multirow[t]{2}{*}{ Constant } & 1.315 & 0.169 \\
\hline & $(0.821)$ & $(0.716)$ \\
\hline \multirow[t]{2}{*}{$\% \triangle E U R E S I D$} & $0.175^{* *}$ & $0.015^{* *}$ \\
\hline & $(0.088)$ & $(0.008)$ \\
\hline \multirow[t]{2}{*}{$\% \triangle I N F L$} & $-0.077^{* *}$ & $-0.024^{* *}$ \\
\hline & $(0.0308)$ & $(0.017)$ \\
\hline \multirow[t]{2}{*}{$\% \triangle U N E M P$} & 0.103 & -0.108 \\
\hline & $(0.163)$ & $(0.136)$ \\
\hline \multirow[t]{2}{*}{$\% \Delta A S X$} & $-4.250^{* * *}$ & $-0.621^{* *}$ \\
\hline & $(0.327)$ & $(0.277)$ \\
\hline \multirow{2}{*}{$\% \triangle R B A C R$} & 0.040 & 0.010 \\
\hline & $(0.325)$ & $(0.281)$ \\
\hline \multirow[t]{2}{*}{$\% \triangle C O N S C O N F$} & -0.034 & -0.013 \\
\hline & $(0.176)$ & $(0.143)$ \\
\hline \multirow{2}{*}{$\% \triangle A U D T W I$} & 0.352 & -0.040 \\
\hline & $(0.324)$ & $(0.269)$ \\
\hline \multirow{2}{*}{$\Delta 3 s 10 \mathrm{~s}$} & 14.827 & -1.866 \\
\hline & (11.240) & $(9.341)$ \\
\hline \multirow[t]{2}{*}{$A R(1)$} & $-0.140^{* * *}$ & $-0.216^{* *}$ \\
\hline & $(0.049)$ & $(0.103)$ \\
\hline Fixed/Random & Fixed & Fixed \\
\hline adj. $R^{2}$ & 0.669 & 0.139 \\
\hline F-Stat & 17.358 & 2.246 \\
\hline No. Obs & 148 & 138 \\
\hline
\end{tabular}

Note: This table presents results from the regression set out in Eq. (7). \% obtained from regressing the election uncertainty variable, $\% \triangle E U$, on macroeconomic variables. Standard errors are in parentheses.

${ }^{* * *},{ }^{* *},{ }^{*}$ denote significance at the $1 \%, 5 \%$, and $10 \%$ levels respectively. 
Table VII

Regression: The influence of political uncertainty on changes in levels of outstanding debt

\begin{tabular}{|c|c|c|c|c|c|c|c|c|c|c|c|c|c|c|c|c|}
\hline \multirow{3}{*}{$\begin{array}{l}\text { Constant } \\
\% \Delta I U\end{array}$} & \multicolumn{4}{|c|}{$\% \Delta S T$ Government Debt Outstanding } & \multicolumn{4}{|c|}{$\% \Delta L T$ Government Debt Outstanding } & \multicolumn{4}{|c|}{$\% \Delta S T$ Non-Government Debt Outstanding } & \multicolumn{4}{|c|}{$\% \Delta L T$ Non-Government Debt Outstanding } \\
\hline & (1) & (2) & (3) & (4) & (1) & (2) & (3) & (4) & (1) & (2) & (3) & (4) & (1) & (2) & (3) & (4) \\
\hline & $\begin{array}{l}1.917^{*} \\
(1.125)\end{array}$ & $\begin{array}{c}1.926^{*} \\
(1.119)\end{array}$ & $\begin{array}{c}1.927^{*} \\
(1.129)\end{array}$ & $\begin{array}{c}1.969^{*} \\
(1.342)\end{array}$ & $\begin{array}{l}2.099^{* * *} \\
(0.479)\end{array}$ & $\begin{array}{l}1.975^{* * *} \\
(0.499)\end{array}$ & $\begin{array}{l}2.096^{* * *} \\
(0.481)\end{array}$ & $\begin{array}{l}2.104^{* * *} \\
(0.482)\end{array}$ & $\begin{array}{l}0.708^{* * *} \\
(0.249)\end{array}$ & $\begin{array}{l}0.659^{* *} \\
(0.258)\end{array}$ & $\begin{array}{l}0.706^{* * *} \\
(0.251)\end{array}$ & $\begin{array}{c}0.714^{* * *} \\
(0.252)\end{array}$ & $\begin{array}{c}2.493^{* * *} \\
(0.590)\end{array}$ & $\begin{array}{c}2.365^{* * *} \\
(0.625)\end{array}$ & $\begin{array}{l}2.491^{* * *} \\
(0.593)\end{array}$ & $\begin{array}{c}2.498^{* * *} \\
(0.599)\end{array}$ \\
\hline$\% \Delta I U$ & $\begin{array}{c}0.089 \\
(0.380)\end{array}$ & $\begin{array}{c}0.135 \\
(0.446)\end{array}$ & $\begin{array}{l}-0.267 \\
(0.654)\end{array}$ & $\begin{array}{c}0.117 \\
(1.087)\end{array}$ & $\begin{array}{l}-0.096 \\
(0.162)\end{array}$ & $\begin{array}{l}-0.284 \\
(0.186)\end{array}$ & $\begin{array}{l}-0.029 \\
(0.278)\end{array}$ & $\begin{array}{l}-0.496 \\
(0.462)\end{array}$ & $\begin{array}{c}0.083 \\
(0.084)\end{array}$ & $\begin{array}{c}0.159 \\
(0.096)\end{array}$ & $\begin{array}{c}0.186 \\
(0.145)\end{array}$ & $\begin{array}{r}-0.006 \\
(0.241)\end{array}$ & $\begin{array}{c}0.126 \\
(0.200)\end{array}$ & $\begin{array}{c}-0.00398 \\
(0.233)\end{array}$ & $\begin{array}{c}0.020 \\
(0.343)\end{array}$ & $\begin{array}{l}-0.074 \\
(0.574)\end{array}$ \\
\hline$\% \triangle E U$ & $\begin{array}{l}-0.344 \\
(0.236)\end{array}$ & $\begin{array}{l}-0.257 \\
(0.301)\end{array}$ & $\begin{array}{l}-0.280 \\
(0.342)\end{array}$ & $\begin{array}{l}-0.062 \\
(0.350)\end{array}$ & $\begin{array}{l}-0.200^{* *} \\
(0.090)\end{array}$ & $\begin{array}{l}-0.327^{* *} \\
(0.125)\end{array}$ & $\begin{array}{l}-0.181^{*} \\
(0.092)\end{array}$ & $\begin{array}{c}-0.170^{* *} \\
(0.074)\end{array}$ & $\begin{array}{l}-0.039 \\
(0.053)\end{array}$ & $\begin{array}{l}-0.082 \\
(0.065)\end{array}$ & $\begin{array}{l}-0.014 \\
(0.075)\end{array}$ & $\begin{array}{l}-0.024 \\
(0.078)\end{array}$ & $\begin{array}{l}-0.055 \\
(0.124)\end{array}$ & $\begin{array}{l}-0.066 \\
(0.157)\end{array}$ & $\begin{array}{l}-0.034 \\
(0.179)\end{array}$ & $\begin{array}{l}-0.336 \\
(0.185)\end{array}$ \\
\hline$\% \Delta I U \cdot L N P$ & $\begin{array}{c}0.182 \\
(0.483)\end{array}$ & $\begin{array}{c}-0.015 \\
(0.598)\end{array}$ & $\begin{array}{c}0.503 \\
(0.633)\end{array}$ & $\begin{array}{c}0.052 \\
(1.217)\end{array}$ & $\begin{array}{l}0.286^{* *} \\
(0.105)\end{array}$ & $\begin{array}{l}0.634^{* *} \\
(0.250)\end{array}$ & $\begin{array}{l}0.207^{* *} \\
(0.096)\end{array}$ & $\begin{array}{l}0.694^{* *} \\
(0.318)\end{array}$ & $\begin{array}{l}-0.145^{* *} \\
(0.067)\end{array}$ & $\begin{array}{l}-0.315^{* *} \\
(0.129)\end{array}$ & $\begin{array}{l}-0.217^{* *} \\
(0.094)\end{array}$ & $\begin{array}{l}-0.018^{*} \\
(0.010)\end{array}$ & $\begin{array}{c}0.026 \\
(0.253)\end{array}$ & $\begin{array}{c}0.002 \\
(0.312)\end{array}$ & $\begin{array}{c}0.006 \\
(0.330)\end{array}$ & $\begin{array}{c}0.109 \\
(0.643)\end{array}$ \\
\hline$\% \triangle E R R$ & $\begin{array}{c}-3.449^{* * *} \\
(0.485)\end{array}$ & $\begin{array}{c}-3.423^{* * *} \\
(0.491)\end{array}$ & $\begin{array}{c}-3.517^{* * *} \\
(0.494)\end{array}$ & $\begin{array}{c}-3.414^{* * *} \\
(0.488)\end{array}$ & $\begin{array}{c}-2.296^{* * *} \\
(0.206)\end{array}$ & $\begin{array}{c}-2.335^{* * *} \\
(0.206)\end{array}$ & $\begin{array}{c}-2.258^{* * *} \\
(0.211)\end{array}$ & $\begin{array}{c}-2.295^{* * *} \\
(0.208)\end{array}$ & $\begin{array}{l}0.837^{* * *} \\
(0.107)\end{array}$ & $\begin{array}{l}0.892^{* * *} \\
(0.106)\end{array}$ & $\begin{array}{l}0.864^{* * *} \\
(0.110)\end{array}$ & $\begin{array}{l}0.861^{* * *} \\
(0.108)\end{array}$ & $\begin{array}{l}-0.019 \\
(0.254)\end{array}$ & $\begin{array}{l}-0.016 \\
(0.257)\end{array}$ & $\begin{array}{c}0.001 \\
(0.260)\end{array}$ & $\begin{array}{l}-0.017 \\
(0.258)\end{array}$ \\
\hline Close_Poll & & $\begin{array}{c}3.796^{*} \\
(2.159)\end{array}$ & & & & $\begin{array}{c}0.522^{*} \\
(0.276)\end{array}$ & & & & $\begin{array}{l}1.234^{* *} \\
(0.550)\end{array}$ & & & & $\begin{array}{l}4.013^{* *} \\
(1.817)\end{array}$ & & \\
\hline$\% \Delta I U \cdot C l o s e \_$Poll & & $\begin{array}{l}-0.114 \\
(0.922)\end{array}$ & & & & $\begin{array}{l}0.706^{*} \\
(0.385)\end{array}$ & & & & $\begin{array}{l}-0.260 \\
(0.199)\end{array}$ & & & & $\begin{array}{c}0.102 \\
(0.482)\end{array}$ & & \\
\hline$\% \triangle E U \cdot C l o s e \_P o l l$ & & $\begin{array}{l}-0.108 \\
(0.599)\end{array}$ & & & & $\begin{array}{c}0.306 \\
(0.250)\end{array}$ & & & & $\begin{array}{c}0.000 \\
(0.130)\end{array}$ & & & & $\begin{array}{c}0.164 \\
(0.313)\end{array}$ & & \\
\hline$\% \Delta I U \cdot L N P \cdot C l o s e \_$Poll & & $\begin{array}{c}0.555 \\
(1.119)\end{array}$ & & & & $\begin{array}{c}-1.084^{* *} \\
(0.468)\end{array}$ & & & & $\begin{array}{l}0.567^{* *} \\
(0.242)\end{array}$ & & & & $\begin{array}{c}0.105 \\
(0.586)\end{array}$ & & \\
\hline Low_ERR & & & $\begin{array}{l}3.191^{* *} \\
(1.317)\end{array}$ & & & & $\begin{array}{c}12.440^{* * *} \\
(3.110)\end{array}$ & & & & $\begin{array}{c}0.127 \\
(1.712)\end{array}$ & & & & $\begin{array}{c}2.766 \\
(4.051)\end{array}$ & \\
\hline$\% \Delta I U \cdot L O W_{-} E R R$ & & & $\begin{array}{c}1.172 \\
(1.115)\end{array}$ & & & & $\begin{array}{l}-0.451 \\
(0.475)\end{array}$ & & & & $\begin{array}{l}-0.086 \\
(0.247)\end{array}$ & & & & $\begin{array}{l}-0.188 \\
(0.586)\end{array}$ & \\
\hline$\% \Delta E U \cdot L o W_{-} E R R$ & & & $\begin{array}{c}0.505 \\
(0.785)\end{array}$ & & & & $\begin{array}{l}-0.325^{* *} \\
(0.158)\end{array}$ & & & & $\begin{array}{c}0.107 \\
(0.174)\end{array}$ & & & & $\begin{array}{l}-0.174 \\
(0.413)\end{array}$ & \\
\hline Contraction & & & & $\begin{array}{c}4.595 \\
(3.255)\end{array}$ & & & & $\begin{array}{c}-0.016 \\
(1.395)\end{array}$ & & & & $\begin{array}{l}-0.083 \\
(0.729)\end{array}$ & & & & $\begin{array}{l}-1.062 \\
(1.730)\end{array}$ \\
\hline$\% \Delta I U \cdot$ Contraction & & & & $\begin{array}{c}0.030 \\
(1.154)\end{array}$ & & & & $\begin{array}{c}0.475 \\
(0.492)\end{array}$ & & & & $\begin{array}{c}0.090 \\
(0.257)\end{array}$ & & & & $\begin{array}{c}0.106 \\
(0.612)\end{array}$ \\
\hline$\% \triangle E U \cdot C o n t r a c t i o n$ & & & & $\begin{array}{l}-0.637 \\
(0.504)\end{array}$ & & & & $\begin{array}{c}-0.141 \\
(0.214)\end{array}$ & & & & $\begin{array}{c}0.133 \\
(0.112)\end{array}$ & & & & $\begin{array}{l}-0.064 \\
(0.266)\end{array}$ \\
\hline$\% \Delta I U \cdot L N P \cdot$ Contraction & & & & $\begin{array}{c}-0.292 \\
(1.529)\end{array}$ & & & & $\begin{array}{l}-0.664 \\
(0.651)\end{array}$ & & & & $\begin{array}{c}-0.205 \\
(0.340)\end{array}$ & & & & $\begin{array}{l}-0.167 \\
(0.807)\end{array}$ \\
\hline Fixed/Random & Fixed & Fixed & Fixed & Fixed & Fixed & Fixed & Fixed & Fixed & Fixed & Fixed & Fixed & Fixed & Fixed & Fixed & Fixed & Fixed \\
\hline adj. $R^{2}$ & 0.341 & 0.343 & 0.346 & 0.352 & 0.539 & 0.558 & 0.511 & 0.548 & 0.573 & 0.598 & 0.545 & 0.577 & 0.037 & 0.004 & 0.039 & 0.039 \\
\hline F-Stat & 9.117 & 6.565 & 7.360 & 6.837 & 20.689 & 15.870 & 16.586 & 15.250 & 23.690 & 18.486 & 18.908 & 17.170 & 0.695 & 0.582 & 0.568 & 0.512 \\
\hline DW & 1.830 & 1.856 & 1.830 & 1.861 & 2.067 & 2.095 & 2.098 & 2.084 & 1.928 & 1.982 & 1.938 & 1.912 & 2.048 & 2.104 & 2.051 & 2.044 \\
\hline No. Obs & 150 & 150 & 150 & 150 & 150 & 150 & 150 & 150 & 150 & 150 & 150 & 150 & 150 & 150 & 150 & 150 \\
\hline
\end{tabular}

three identified political uncertainty variables (Incumbent Uncertainty, $I U$, and Election Uncertainty, $E U$, and an interaction term between Incumbent Uncertainty and the incumbent Prime Minister been a member of the LNP Coalition), and a control variable for the macroeconomic risk factors (ERR). Indicators for close polling results (the narrowest quintile of poll results), high economic risk factors (defined as low $E R R$ ), and business cycle contraction are also included. A effects panel specification is used. Standard errors in parentheses.

${ }^{* * *}, * *,{ }^{*}$ denote significance at the $1 \%, 5 \%$, and $10 \%$ levels respectively. 
Table VIII

Regression: Influence of political uncertainty on issuance of long-term Government bonds

\begin{tabular}{|c|c|c|c|c|c|c|c|c|}
\hline & \multicolumn{2}{|c|}{$\% \Delta \$ A$ mount Issued } & \multicolumn{2}{|c|}{$\% \Delta$ Coverage ratio of issue } & \multicolumn{2}{|c|}{$\% \Delta A$ ve. maturity of bonds } & \multicolumn{2}{|c|}{$\% \Delta$ Yield of bonds } \\
\hline & (1) & (2) & (1) & (2) & (1) & (2) & $(1)$ & (2) \\
\hline \multirow[t]{2}{*}{ Constant } & $1.030^{*}$ & $0.351^{*}$ & $0.459^{*}$ & $0.900^{* *}$ & 0.075 & 3.186 & $-0.690^{* *}$ & $-0.291^{* *}$ \\
\hline & $(1.487)$ & $(1.152)$ & $(0.265)$ & $(0.482)$ & $(4.900)$ & $(5.165)$ & $(0.271)$ & $(0.136)$ \\
\hline \multirow[t]{2}{*}{$\% \Delta I U$} & -0.027 & -0.887 & 1.052 & 0.966 & 1.459 & 2.331 & 0.202 & 0.439 \\
\hline & $(1.524)$ & $(1.909)$ & $(0.670)$ & $(0.832)$ & $(1.238)$ & $(1.511)$ & $(0.271)$ & $(0.336)$ \\
\hline \multirow[t]{2}{*}{$\% \Delta E U$} & $-0.816^{* *}$ & $-0.618^{* *}$ & $-0.076^{* *}$ & $-0.030^{* *}$ & $-0.594^{* *}$ & 1.695 & $0.565^{* *}$ & $0.808^{* * *}$ \\
\hline & $(0.347)$ & $(0.275)$ & $(0.029)$ & $(0.012)$ & $(0.294)$ & $(1.246)$ & $(0.240)$ & $(0.277)$ \\
\hline \multirow[t]{2}{*}{$\% \Delta I U \cdot L N P$} & $1.237^{* *}$ & $0.275^{*}$ & -0.323 & -0.659 & -0.227 & -1.794 & -0.517 & $-1.012^{*}$ \\
\hline & $(0.564)$ & $(0.155)$ & $(1.171)$ & $(1.418)$ & (2.163) & $(2.576)$ & $(0.474)$ & $(0.573)$ \\
\hline \multirow[t]{2}{*}{$\% \triangle E R R$} & $-2.900^{* *}$ & $-3.030^{* *}$ & $0.442^{*}$ & $0.395^{*}$ & -0.024 & 0.169 & 0.503 & 0.544 \\
\hline & $(1.155)$ & $(1.189)$ & $(0.247)$ & $(0.200)$ & $(1.750)$ & $(1.733)$ & $(0.386)$ & $(0.385)$ \\
\hline \multirow[t]{2}{*}{ Close_Poll } & & $-7.587^{* *}$ & & 3.235 & & -15.095 & & -0.206 \\
\hline & & $(19.550)$ & & $(8.517)$ & & (15.397) & & $(3.288)$ \\
\hline \multirow[t]{2}{*}{$\% \Delta I U \cdot C l o s e \_P o l l$} & & 2.795 & & 0.389 & & -2.923 & & -0.705 \\
\hline & & $(3.352)$ & & $(1.460)$ & & $(2.653)$ & & $(0.582)$ \\
\hline \multirow[t]{2}{*}{$\% \triangle E U \cdot C l o s e \_P o l l$} & & 1.079 & & 0.922 & & $-5.762^{* *}$ & & $1.047^{*}$ \\
\hline & & $(3.553)$ & & $(1.548)$ & & $(2.812)$ & & $(0.613)$ \\
\hline \multirow[t]{2}{*}{$\% \Delta I U \cdot L N P \cdot C l o s e \_$Poll } & & $-2.493^{* *}$ & & 1.867 & & 3.897 & & 1.433 \\
\hline & & $(6.331)$ & & $(2.758)$ & & $(5.011)$ & & $(1.104)$ \\
\hline Fixed/Random & Fixed & Fixed & Fixed & Fixed & Fixed & Fixed & Fixed & Fixed \\
\hline adj. $R^{2}$ & 0.128 & 0.137 & 0.047 & 0.073 & 0.043 & 0.099 & 0.093 & 0.132 \\
\hline F-Stat & 0.306 & 0.286 & 0.524 & 0.580 & 0.469 & 0.810 & 1.106 & 1.154 \\
\hline DW & 3.580 & 3.603 & 2.365 & 2.341 & 3.159 & 2.967 & 2.517 & 2.381 \\
\hline No. Obs & 93 & 93 & 93 & 93 & 93 & 93 & 93 & 93 \\
\hline
\end{tabular}

Note: This table presents results from the regression whereby the percentage change in factors of long-term Government debt issuance (Source: AOFM.gov.au), namely the $\$$ amount issued, coverage ratio of bonds issued, average maturity of bonds issued, and yield of bonds issued, are regressed on the percentage change in the three identified political uncertainty variables (Incumbent Uncertainty, IU, and Election Uncertainty, $E U$, and an interaction term between Incumbent Uncertainty and the incumbent Prime Minister been a member of the LNP Coalition), and a control variable for the macroeconomic risk factors (ERR). Indicators for close polling results (the narrowest quintile of poll results)are also included. A fixed time effects panel specification is used. Standard errors in parentheses. ${ }^{* * *},{ }^{* *},{ }^{*}$ denote significance at the $1 \%, 5 \%$, and $10 \%$ levels respectively. 